\title{
REAL EXCHANGE RATE MISALIGNMENT AND BUSINESS CYCLE FLUCTUATIONS IN ASIA AND THE PACIFIC
}

Dessie Ambaw, Madhavi Pundit, Arief Ramayandi, and Nicholas Sim

NO. 651

March 2022
ADB ECONOMICS WORKING PAPER SERIES 


\section{ADB Economics Working Paper Series}

\section{Real Exchange Rate Misalignment and Business Cycle Fluctuations in Asia and the Pacific}

Dessie Ambaw, Madhavi Pundit, Arief Ramayandi, and Nicholas Sim

No. 651 | March 2022
Dessie Ambaw (dessie.ambaw@unisa.edu.au) is a lecturer at UniSA Business, University of South Australia, Australia. Nicholas Sim (nicholassimcs@suss. edu.sg) is an associate professor at Singapore University of Social Sciences. Arief Ramayandi (aramayandi@adb.org) is a principal economist and Madhavi Pundit (mpundit@adb.org) is an economist at the Economic Research and Regional Cooperation Department, Asian Development Bank.

The authors would like to thank Abdul Abiad for his insights and support; and Priscille Villanueva for his valuable research assistance. 
(C) 2022 Asian Development Bank 6 ADB Avenue, Mandaluyong City, 1550 Metro Manila, Philippines

Tel +632 8632 4444; Fax +63286362444

www.adb.org

Some rights reserved. Published in 2022.

ISSN 2313-6537 (print), 2313-6545 (electronic)

Publication Stock No. WPS220066-2

DOI: http://dx.doi.org/10.22617/WPS220066-2

The views expressed in this publication are those of the authors and do not necessarily reflect the views and policies of the Asian Development Bank (ADB) or its Board of Governors or the governments they represent.

ADB does not guarantee the accuracy of the data included in this publication and accepts no responsibility for any consequence of their use. The mention of specific companies or products of manufacturers does not imply that they are endorsed or recommended by ADB in preference to others of a similar nature that are not mentioned.

By making any designation of or reference to a particular territory or geographic area, or by using the term "country" in this document, $A D B$ does not intend to make any judgments as to the legal or other status of any territory or area.

This work is available under the Creative Commons Attribution 3.0 IGO license (CC BY 3.0 IGO)

https://creativecommons.org/licenses/by/3.0/igo/. By using the content of this publication, you agree to be bound by the terms of this license. For attribution, translations, adaptations, and permissions, please read the provisions and terms of use at https://www.adb.org/terms-use\#openaccess.

This CC license does not apply to non-ADB copyright materials in this publication. If the material is attributed to another source, please contact the copyright owner or publisher of that source for permission to reproduce it. ADB cannot be held liable for any claims that arise as a result of your use of the material.

Please contact pubsmarketing@adb.org if you have questions or comments with respect to content, or if you wish to obtain copyright permission for your intended use that does not fall within these terms, or for permission to use the ADB logo.

Corrigenda to ADB publications may be found at http://www.adb.org/publications/corrigenda.

Notes:

In this publication, "\$” refers to United States dollars.

ADB recognizes "Hong Kong” as Hong Kong, China.

The ADB Economics Working Paper Series presents data, information, and/or findings from ongoing research and studies to encourage exchange of ideas and to elicit comment and feedback about development issues in Asia and the Pacific. Since papers in this series are intended for quick and easy dissemination, the content may or may not be fully edited and may later be modified for final publication. 


\section{CONTENTS}

TABLES AND FIGURES iv

ABSTRACT

$\begin{array}{lll}\text { I. INTRODUCTION } & 1\end{array}$

II. BACKGROUND $\quad \mathbf{2}$

A. Real Exchange Rate Misalignment, Economic Growth, and Currency Crisis 2

B. Real Exchange Rate Misalignment and the Business Cycle 3

$\begin{array}{ll}\text { III. DATA } & 4\end{array}$

A. Summary Statistics 6

B. Comparison with Other Real Exchange Rate Misalignment Models 10

$\begin{array}{ll}\text { IV. METHODOLOGY } & 14\end{array}$

A. The Model $\quad 14$

B. Preliminary Diagnostics 14

V. RESULTS $\quad 16$

A. Baseline Results 16

B. Robustness Checks 18

C. Variance Decomposition 24

VI. ECONOMY-SPECIFIC BAYESIAN VECTOR AUTOREGRESSION 24

$\begin{array}{ll}\text { VII. CONCLUSION } & 30\end{array}$

$\begin{array}{ll}\text { REFERENCES } & 31\end{array}$ 


\section{TABLES AND FIGURES}

\section{TABLES}

1 Summary Statistics $\quad 6$

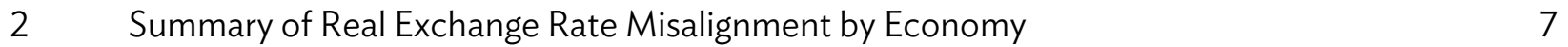

3 Cross-Sectional Dependence Test 15

$4 \quad$ Unit Root Test with Cross-Sectional Dependence 15

5 Variance Decomposition 24

\section{FIGURES}

$1 \quad$ Real Exchange Rate Misalignment Index $\quad 8$

2 Real Exchange Rate Misalignment over the Business Cycle 9

3 Real Exchange Rate Misalignment Index, CEPII and ADB 11

$4 \quad$ Real Exchange Rate Misalignment Index, ADB and IMF 13

5 Baseline Impulse Response Functions 16

6 Reverse Ordering of Variables in the Baseline Model 18

$7 \quad$ Impulse Responses for Economies with Volatile Real Exchange Rate 19

8 Impulse Responses for Economies with Stable Real Exchange Rate 20

9 Impulse Response Based on Forward Orthogonal Deviation Transformation 21

10 Impulse Response, Excluding Interest Rate 22

11 Impulse Response, Credit-to-GDP Gap 23

12 Impulse Response from Orthogonalized Misalignment Shock—Selected Economies 26 in Southeast Asia

13 Impulse Response from Orthogonalized Misalignment Shock-Hong Kong, China and 27 the People's Republic of China

14 Impulse Response from Orthogonalized Misalignment Shock—Selected Economies 28 in Central Asia

15 Impulse Response from Orthogonalized Misalignment Shock-Fiji and the Solomon Islands 


\begin{abstract}
Real exchange rate (RER) misalignment, which is the deviation between the actual real exchange rate from its equilibrium, occurs frequently among developing economies. Studies have shown that RER misalignment may have negative economic implications, such as a reduction in economic growth, exports and export diversification, and an increased risk of currency crises and political instability. Using quarterly data for 22 sample economies from 1990 to 2018, this paper investigates the impact of RER misalignment on business cycles in Asia and the Pacific by employing a panel vector autoregression involving consumer price index (CPI) inflation, output gap, short-term interest rate, and RER misalignment. We find that RER overvaluation may lead to a reduction in CPI inflation and short-term interest rate. We also find that Asia and the Pacific is highly heterogeneous wherein the output gaps of some economies, particularly those in Southeast Asia, are more susceptible to RER misalignment shocks.
\end{abstract}

Keywords: real exchange rate misalignment, business cycle fluctuations

JEL codes: D74, E32, F31, F41, O11 


\section{INTRODUCTION}

The real exchange rate (RER) misalignment is the deviation of the actual RER from its equilibrium. Studies have found that RER misalignment may impact developing economies negatively in several ways. For example, RER overvaluation may lead to slower economic growth (Ghura and Grennes 1993; Rodrik 2008; and Elbadawi, Kaltani, and Soto 2012), reduce export volumes (Pick and Vollrath 1994, Sekkat and Varoudakis 2000), constrain export diversification (Sekkat 2016), and foster currency crises (Holtemöller and Mallick 2013) and political instability and conflict (Ambaw and Sim 2021). These studies, however, usually focus on the impact of RER misalignment in the long run: how RER misalignment affects the economy in the short to medium run is not well-known.

In this paper, we investigate the role of RER misalignment on the business cycle for 22 economies in Asia and the Pacific. RER misalignment frequently occurs among developing economies in this region. For example, following the dissolution of the Union and Commonwealth of Independent States, the RERs of Armenia and Georgia were undervalued relative to their equilibrium levels in the early 1990s. During the Asian Financial Crises, Indonesia's RER was significantly misaligned, and after the Global Financial Crisis, its currency was persistently weakened. As RER misalignment has various ramifications, it is important to explore if RER misalignment has had negative economic impacts for Asia and the Pacific. RER overvaluation, for instance, discourages exports, which in turn, may lead to slower economic growth. Importantly, as the region is becoming more open, one might be concerned that RER shocks may themselves be a source of business cycle fluctuations.

To explore the impact of RER misalignment in Asia and the Pacific, we construct quarterly data on RER misalignment for a set of economies following the approach of (Elbadawi, Kaltani, and Soto 2012). We then study the role of RER misalignment on the business cycle for our pooled sample using panel vector autoregression (VAR). We estimate a four-variable panel VAR, ordered by consumer price index $(\mathrm{CPI})$ inflation, output gap, short-term interest rate, and RER misalignment, and include fixed effects for each economy to eliminate the confounding effects of unobserved heterogeneity. We then examine the impulse responses based on a one-standard deviation orthogonalized shock from each variable.

We find that RER misalignment is mainly affected by CPI inflation and interest rate, but not by output gap. On the flip side, a shock to RER misalignment is associated with an eventual increase in $\mathrm{CPI}$ inflation and short-term interest rate, and an output gap that becomes negative. This suggests at first glance that RER misalignment shock may propagate business cycles in the region.

Given that Asia and the Pacific is highly heterogeneous, we estimate an economy-specific model using the Bayesian VAR. The Bayesian VAR addresses the problem of the curse of dimensionality inherent in the standard VAR. This is important since compared to panel VAR, the number of observations at the economy level is significantly smaller. From the Bayesian VAR, we find that the response of $\mathrm{CPI}$ inflation and interest rate to an RER misalignment shock is generally similar to the responses observed from the pooled regressions. However, the response of output gap is substantially varied across economies in the region. For Southeast Asian economies such as Indonesia, the Philippines, Singapore, and Thailand, an RER overvaluation shock may lead to a substantial decline in output relative to its trend. An increasingly negative output gap, following an RER overvaluation shock, can also be observed in Central Asian economies such as Azerbaijan and the Kyrgyz Republic. However, there is no evidence that RER misalignment affects the output gap of Hong Kong, China; and 
the People's Republic of China (PRC). This suggests that the effects of RER misalignment on the business cycle are heterogeneous across the region.

This paper discusses the potential role of RER misalignment shocks as a source of business cycle fluctuations. It offers some stylized facts on how RER misalignment interacts with the macroeconomic indicators of economies in Asia and the Pacific. From a policy perspective, it suggests that the management of currency misalignment may help to promote price and output stability.

\section{BACKGROUND}

RER misalignment has both economic and social implications. In this section, we summarize a few key findings from the literature on how RER misalignment affects developing economies.

\section{A. Real Exchange Rate Misalignment, Economic Growth, and Currency Crisis}

Economic growth. Many studies have shown that RER misalignment, particularly RER overvaluation, is associated with lower levels of growth, as it directly reduces the demand for goods in the tradable sector. ${ }^{1}$ RER misalignment is also associated with institutional weaknesses and market failures that characterize many low-income economies, and these structural issues tend to impact the tradable sector strongly, leading to lower levels of growth (Rodrik 2008).

In empirical studies, one could be concerned that RER misalignment is endogenous for growth. However, it is unlikely that the observed impact of RER misalignment on growth is entirely driven by endogeneity. ${ }^{2}$ For instance, using a panel of more than 150 economies in the post-Bretton Woods period, studied how movements in the RER could affect growth. Employing (external) instrumental variables to disentangle the effect of RER misalignment on growth from reversal causality, they found that RER appreciation (or depreciation) had a stronger observed effect on annual real gross domestic product (GDP) growth compared to what was previously reported where RER misalignment was not instrumented. Therefore, they found no evidence that the observed negative effect of RER misalignment on growth is due solely to RER misalignment being potentially endogenous.

Exports. Given that RER misalignment may impact economic growth by affecting the tradable sector, it is natural to infer that RER misalignment would affect exports as well. Ghura and Grennes (1993), for instance, showed that RER overvaluation could reduce the amount of exports produced by acting as an implicit tax on profits produced by exports. Empirically, Pick and Vollrath (1994) estimated the effect of RER misalignment on agricultural exports and found that RER misalignment had a strong negative effect on it. Elbadawi (1998) further demonstrated that the negative effect of RER misalignment on export was present even after controlling for RER volatility. Given that RER

1 For example, Cottani, Cavallo, and Khan (1990) first found that RER misalignment (in the form of overvaluation) had a strong negative impact on growth for developing economies across Asia, Latin America, and Africa. Ghura and Grennes (1993) later affirmed that such negative effects were also present for countries in sub-Saharan Africa (SSA).

2 This is because RER misalignment is usually constructed using economic fundamentals that are most likely correlated with the "unobservables" of the macro-dependent variable (e.g., economic growth) that the RER misalignment measure serves as a regressor. 
misalignment and volatility are correlated, their results showed RER misalignment affects exports beyond the effects of RER volatility.

For developing economies, the negative effects of RER misalignment are found in both agricultural and non-agricultural exports. For example, Sekkat and Varoudakis (2000) found that in developing economies, RER overvaluations tend to be followed by declines in manufacturing exports. Conversely, Freund and Pierola (2012) found that large RER undervaluations tend to be followed by surges in manufacturing exports, defined as "significant and sustained increase in export growth from one seven-year period to the next". Sekkat (2016) also found that RER misalignment could affect export diversification in developing economies.

Because RER misalignment affects exports, it may potentially be welfare reducing. One reason, Engel (2011) argued, is that RER misalignment leads to resource allocation problems.

When exchange rates are misaligned, households in the home and foreign countries may pay different prices for the identical good. This would be inefficient and welfare reducing if the good's marginal cost is the same irrespective of where the good is sold. ${ }^{3}$ As such, Engel (2014) argued that policy makers could target currency misalignment and global imbalances in addition to the goals of stabilizing inflation and the output gap. ${ }^{4}$

Political stability. Recently, Ambaw and Sim (2021) showed that RER misalignment may affect political stability. Using a panel of 35 sub-Saharan African countries from 1975 to 2006, they found that RER misalignment could lead to more civil conflict despite controlling for rainfall and commodity price shocks - two widely known factors of civil conflict. Their findings suggest that political stability may be promoted by achieving RER stabilization and managing currency misalignment.

Currency crises. Holtemöller and Mallick (2013) and Heriqbaldi et al. (2020) showed that currency misalignment were precursors of currency crises. For instance, to assess if misalignment could be used as an indicator of potential financial crisis, Holtemöller and Mallick (2013) looked at the ability of RER misalignment to predict the probability of a currency crisis in the next period. They showed that large and persistent misalignment were informative about macroeconomic crises. Heriqbaldi, Widodo, and Ekowati (2020) looked at whether the misalignment of the Indonesian rupiah contributed to the exchange rate crisis in the country. They found that 10 of the 17 crisis episodes related to the rupiah could be traced to large shocks to RER misalignment.

\section{B. Real Exchange Rate Misalignment and the Business Cycle}

The relevance of RER misalignment for the business cycle has gained some attention recently. One group of studies explores the extent to which RER misalignment is linked with current account balances. Based on a sample of 22 industrialized economies, Gnimassoun and Mignon (2015) found that RER misalignments, particularly RER overvaluations, could increase the size and persistence of

3 As such, Engel (2011) shows that these violations lead to a reduction in world welfare, suggesting optimal monetary policy should target RER misalignments along with inflation and output gap goals.

4 Engel (2014) further argues that optimal policies may involve targeting the exchange rate both directly, because of currency misalignment, and indirectly, because of the effects of exchange rates on imbalances, inflation, and output gaps. 
current account imbalances. ${ }^{5}$ Similarly, using a Bayesian panel VAR approach on 27 economies over the 1994-2012 period, Comunale (2021) studied the interaction among RER misalignment, current account misalignment, and financial gaps in the EU. Comunale observed that RER misalignment shocks had a negative impact on financial and output gaps, where RER misalignment could, in turn, be affected by current account misalignment shocks.

The second group of studies looks more generally at how RER misalignment affects macroeconomic performance. Gnimassoun and Mignon (2016) studied the interactions among output gap (which reflects internal imbalances), current account discrepancies (which represent external imbalances), and RER misalignments for a sample of 22 industrialized economies over the period 1980-2011. They found that the three macroeconomic imbalances were strongly related, and RER overvaluation could deepen current account deficits. Using RER misalignment as a measure of competitiveness, Lewis, Martin, and Bella (2007) and Staehr and Vermeulen (2016) showed that negative competitiveness shock could reduce GDP growth for several quarters in Eurozone countries, but had little explanatory power on domestic credit and current account balance. ${ }^{6}$

\section{DATA}

We contribute to the literature by exploring the relevance of RER misalignment for the business cycle through a panel VAR. Our data comprise a quarterly panel from the first quarter (Q1) of 1990 to Q4 2018 of 22 economies from Asia and the Pacific listed in Appendix Table A1.1. ${ }^{7}$ We estimate a four-variable panel VAR consisting of the CPI inflation (cpi inf), output gap (output gap), short-term interest rate (irate), and RER misalignment (misalign). We also consider the credit-to-output gap (crgdp gap) in place of output gap to gauge the impact on financial cycle. ${ }^{8}$

Consumer price index inflation and interest rate. CPI inflation is defined as the quarterly difference in the log of the price index. Domestic interest rates are the 3-month interbank offer rates from each economy in the sample.

Output gap and credit-to-output gap. We construct the output gap and credit-to-output gap as follows. First, we transform each into log. Then, we use the Christiano-Fitzgerald (CF) filter to decompose each series into a cyclical and trend component. The cyclical component of each series reflects the gap of output and credit-to-output from their respective trends. The standardized cyclical component is then used as the measure of output and credit-to-output gaps for our VAR analysis. ${ }^{9}$

Real exchange rate misalignment. We construct the RER misalignment index for each economy. RER misalignment is the deviation of the observed RER from its equilibrium, defined as the

5 They showed that persistence in current account imbalances tends to increase for overvaluations that are larger than $11 \%$ for Euro area and 14\% for the non-Euro area.

6 Staehr and Vermeulen (2016) used the real effective exchange rate as one of the measures of competitiveness.

7 The appendix can be accessed here: https://www.adb.org/publications/real-exchange-rate-misalignment-business-cyclefluctuations.

8 When the data are available only annually, the Denton method is applied to disaggregate them into quarterly series.

9 For example, let output gap be the output gap generated by the CF filter. The standardized output gap is:

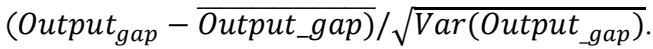


RER that simultaneously attains both domestic equilibrium (i.e., the clearance of the non-tradable sector) and external equilibrium (i.e., the present and future current account balances that are compatible with long-run capital flows) (Nurkse 1945, Edwards 1989). ${ }^{10}$ In this section, we briefly describe how the RER misalignment index is constructed. The full discussion can be found in Appendix 2.C (footnote 7).

We follow Elbadawi, Kaltani, and Soto (2012) to construct the RER misalignment index as the difference between the RER in logs $\left(\ln \left(R E R_{i t}\right)\right)$ and its equilibrium level $\left(\ln \left({ }^{\wedge} R E R_{i t}\right)\right)$ :

$$
\text { misalign }_{i t}=\operatorname{In}\left(R E R_{i t}\right)-\operatorname{In}\left({ }^{\wedge} R E R_{i t}\right) \text {. }
$$

Therefore, to construct the RER misalignment index, we need to first estimate the equilibrium RER (i.e., $\left.\ln \left(\widehat{R E R_{l t}}\right)\right)$. To do so, recall that the RER depends on both domestic and external factors." To estimate the equilibrium RER, we first regress the log of RER $\left(\ln \left(R E R_{i t}\right)\right.$ ) on both external and domestic fundamentals represented by the vector $\mathbf{F}_{i t}$ :

$$
\operatorname{In}\left(R E R_{i t}\right)=\alpha_{i}+\beta_{0} \mathrm{~F}_{i t}+\varepsilon_{i t}
$$

The external fundamentals consist of the terms of trade, net foreign asset, international interest rate, and foreign aid as a percentage of GDP. The domestic fundamentals consist of a measure of productivity capturing the Balassa-Samuelson effect, the ratio of government expenditure to GDP, and trade openness. The variables used as external and internal fundamentals are listed in Appendix Table A1.2 (footnote 7).

Once we have obtained an estimate of equation 2, we will use it to predict the equilibrium RER. This is done by first extracting the long run components of the fundamentals using the HodrickPrescott (HP) filter, and then imputing these long run components back into the estimation equation:

$$
\operatorname{In}\left(\widetilde{R E R}_{i t}\right)=\widetilde{\gamma}_{l}+\hat{\beta}^{\prime} \mathrm{F}_{i t}^{S}
$$

$\ln \left(R \widetilde{E R_{l t}}\right)$ is the estimate of the equilibrium RER, which for each economy, is plotted in Figure A1.1 of Appendix $1 .{ }^{10}$ After obtaining the equilibrium RER for each economy, we then compute the economy's RER misalignment index based on equation 1.

In terms of interpretation, note that the RER misalignment index is defined as the difference between the log of the RER and the log of its equilibrium. Thus, the distance between the RER and its equilibrium is defined in terms of log points. To convert it into a percentage that expresses how many percent the RER is above or below its equilibrium, we use the formula:

$$
100[\exp (\text { misalign }-1)=100(\exp (\operatorname{In}(R E R)-\ln (R \widetilde{E R})))-1]
$$

10 In other words, the equilibrium RER is "the value of the RER that is consistent with the dual objectives of external and internal balance, for specified values of other variables that may influence these objectives. The former refers to $a$ situation in which the value of the current account deficit is one that can be financed by a 'sustainable' level of capital inflows, while the latter refers to a situation in which the market for non-traded goods is in a 'sustainable' equilibrium" (Montiel 1999).

11 Please see MacDonald (2000) for a brief review on the various theoretical and empirical models of equilibrium RER determination. 


\section{A. Summary Statistics}

Table 1 presents the summary statistics of the five macroeconomic indicators (abbreviated names in parentheses) considered in our VAR. The summary statistics are based on pooled data from 22 economies between Q1 1990 to Q4 2018.

Table 1: Summary Statistics

\begin{tabular}{|c|c|c|c|c|}
\hline Variable & Mean & SD & Minimum & Maximum \\
\hline CPI inflation (cpi inf) & 0.01774 & 0.0727 & -0.0859 & 2.3589 \\
\hline Output gap (output gap) & $3.85 e-10$ & 0.9944 & -3.7339 & 2.9744 \\
\hline Credit-to-output gap (crgdp gap) & $6.28 e-10$ & 0.9939 & -2.9023 & 2.7016 \\
\hline Short-term interest rate (irate) & 6.781508 & 5.482151 & 0.0005 & 56.1557 \\
\hline RER misalignment (misalign) & $2.24 e-09$ & 0.1562 & -1.2671 & 0.5307 \\
\hline
\end{tabular}

$\mathrm{CPI}=$ consumer price index, $\mathrm{RER}=$ real exchange rate, $\mathrm{SD}=$ standard deviation.

Note: See Appendix Table A1.3 for the definition of variables used for panel vector autoregression. The appendix can be accessed here: https://www.adb.org/publications/real-exchange-rate-misalignment-business-cycle-fluctuations.

Source: Authors' calculations using data from CEIC Data Company, Federal Reserve Economic Data, and Haver Analytics (accessed 2 August 2020).

$\mathrm{CPI}$ inflation is defined as the quarter-on-quarter (i.e., quarterly) inflation rate. A $1 \%$ inflation rate is represented by a value of 0.01 . From Table 1 , the average quarterly CPI inflation is $1.77 \%$. The highest rate of quarterly inflation is 235.89\%, which took place in Armenia in Q4 1993 during the early years of its independence from the former Soviet Union.

The output gap is the deviation of the log of output from its trend. Thus, the output gap itself approximates the deviation of output gap from its trend in log points. The average output gap for our sample of Asia and the Pacific economies is 0.9944 log point. The maximum output gap in the sample is 2.9744, which corresponds to Tajikistan in Q4 1993. The minimum output gap is -3.7339 , which corresponds to Papua New Guinea in Q1 1999. In the sample, extreme negative output gaps are more common than extreme positive output gaps, suggesting that extreme declines in output relative to its trend are more common than the opposite. For instance, besides Tajikistan in Q4 1993, output gap exceeded 2.9 only twice, i.e., by Indonesia in Q1 and Q2 1997. By contrast, output gap was below -3 for Indonesia, Malaysia, Papua New Guinea, and the Republic of Korea, between Q3 1998 and Q2 1999 during the Asian Financial Crisis, and for Singapore between Q1 and Q2 2009 during the Global Financial Crisis.

Like the output gap, the credit-to-output gap is defined in log points. Its mean of 0.9939 , interestingly, is similar to the mean of the output gap (i.e., 0.9944). However, unlike the output gap, the negative and positive extremes of the credit-to-output gap are more similar in magnitude. Here, the three largest negative data points come from Thailand between Q2 and Q4 2001 and in Q1 of 2000. The three largest positive data points come from Thailand in Q1 2000, Malaysia in Q4 2009, and Singapore in Q4 2008. For the Malaysia and Singapore, it might seem puzzling that the large positive credit-to-output gaps had happened during the Global Financial Crisis. However, it turned out that these positive values quickly became negative thereafter, suggesting that the adjustment of credit-to-output gap followed the onset of the Global Financial Crisis with a lag. 
For interest rate, a value of 1 for irate in Table 1 corresponds to an interest rate of $1 \%$. The mean interest rate in the sample is $5.482 \%$. The maximum interest rate in the sample is 56.1557 , which corresponds to Indonesia in Q3 1998 during the onset of the Asian Financial Crisis. ${ }^{12}$

Finally, the largest undervaluation episode (i.e., negative RER misalignment) in the dataset is similar in magnitude to the largest overvaluation episode (i.e., positive RER misalignment). This can be seen in Table 2, where we report the summary statistics of RER misalignment for each economy. Here, the largest negative value observed for RER misalignment is -1.2671 , which corresponds to Georgia in Q4 1993. This implies that the RER of Georgia is -1.2671 log points below its equilibrium. In percentage terms, the RER was $71.8 \%$ undervalued relative to its equilibrium in that quarter (but as discussed below, the undervaluation did not last long).

Table 2: Summary of Real Exchange Rate Misalignment by Economy

\begin{tabular}{|c|c|c|c|c|}
\hline Economy & Mean & SD & Minimum & Maximum \\
\hline Armenia & $1.46 e-07$ & 0.2388 & -0.9121 & 0.2507 \\
\hline Azerbaijan & $2.30 e-07$ & 0.1430 & -0.3191 & 0.1561 \\
\hline China, People's Republic of & $-1.60 e-07$ & 0.1592 & -0.2260 & 0.4147 \\
\hline Fiji & $-1.93 e-07$ & 0.0891 & -0.1603 & 0.2039 \\
\hline Georgia & $-9.25 e-08$ & 0.3952 & -1.2671 & 0.3183 \\
\hline Hong Kong, China & $6.99 e-08$ & 0.1030 & -0.3104 & 0.1578 \\
\hline Indonesia & 0 & 0.2113 & -0.4795 & 0.3227 \\
\hline Kazakhstan & $1.52 \mathrm{e}-07$ & 0.2738 & -0.4488 & 0.5307 \\
\hline Korea, Republic of & $1.27 e-07$ & 0.0761 & -0.3378 & 0.1449 \\
\hline Kyrgyz Republic & $-2.59 e-07$ & 0.0843 & -0.1372 & 0.1728 \\
\hline Malaysia & $-1.69 e-07$ & 0.1498 & -0.2468 & 0.2684 \\
\hline Mongolia & $-2.47 e-07$ & 0.0649 & -0.1360 & 0.2519 \\
\hline Pakistan & $-3.29 e-08$ & 0.0846 & -0.1468 & 0.1858 \\
\hline Papua New Guinea & $7.40 e-08$ & 0.1039 & -0.2510 & 0.2293 \\
\hline Philippines & $-1.23 e-07$ & 0.0647 & -0.1516 & 0.1789 \\
\hline Singapore & $-1.85 e-07$ & 0.0378 & -0.0674 & 0.0971 \\
\hline Solomon Islands & $-8.63 e-08$ & 0.1578 & -0.3337 & 0.2803 \\
\hline Sri Lanka & $4.11 e-08$ & 0.1247 & -0.1882 & 0.2112 \\
\hline Tajikistan & 1.97e-07 & 0.1677 & -0.2983 & 0.2446 \\
\hline Thailand & $1.03 e-07$ & 0.0390 & -0.2008 & 0.0941 \\
\hline Viet Nam & $2.26 e-07$ & 0.0518 & -0.0918 & 0.1397 \\
\hline
\end{tabular}

$\mathrm{SD}=$ standard deviation.

Source: Authors' calculations using data from CEIC Data Company, Federal Reserve Economic Data, and Haver Analytics (accessed 2 August 2020).

12 During the Asian Financial Crisis, the Indonesian rupiah lost about $70 \%$ of its value. Because many Indonesian companies borrowed offshore, the decline in the rupiah had caused large losses. To stem a full-scale financial crisis in Indonesia and to restore confidence in the rupiah, the IMF offered Indonesia with a bailout package totaling $\$ 43$ billion and advised the Indonesian central bank (Bank Indonesia) to raise interest rates. 
In contrast to Georgia, the largest positive value observed for RER misalignment is 0.5307 , which corresponds to Kazakhstan in Q1 1999. In percentage terms, the currency was overvalued by $70.0 \%$ in that period (compared to the $71.8 \%$ undervaluation of Georgia's RER). Interestingly, the RER misalignment index of the former Soviet Union states tend to be more highly volatile. Georgia, for instance, has the most volatile RER misalignment index with a standard deviation of 0.3952 . Kazakhstan has the next most volatile RER misalignment index with a standard deviation is 0.2738.

To visualize how RER misalignment varies over time, Figure 1 plots the series for each of the 22 Asia and the Pacific economies from Q1 1990 to Q4 2018. The Philippines, Singapore, Thailand, and Viet Nam have stable RERs during the sample period, where their misalignment indices are mostly close to zero. There is unambiguous evidence of RER misalignment for Armenia and Georgia in the early 1990s following the dissolution of the Soviet Union and Commonwealth of Independent States. For example, in the first half of the 1990s, the Armenian dram and the Georgian lari were negatively misaligned by about 1 log point, or approximately 63\%, from the equilibrium RER. However, the negative misalignment was quickly reversed for these currencies, which have been stable ever since.

While the misalignment of the dram and the lari was short-lived, it is not always the case that misaligned currencies quickly converge to their equilibrium. In fact, Figure 1 shows that the misalignment of exchange rates can be persistent. For example, the Kazakhstan tenge was negatively misaligned since

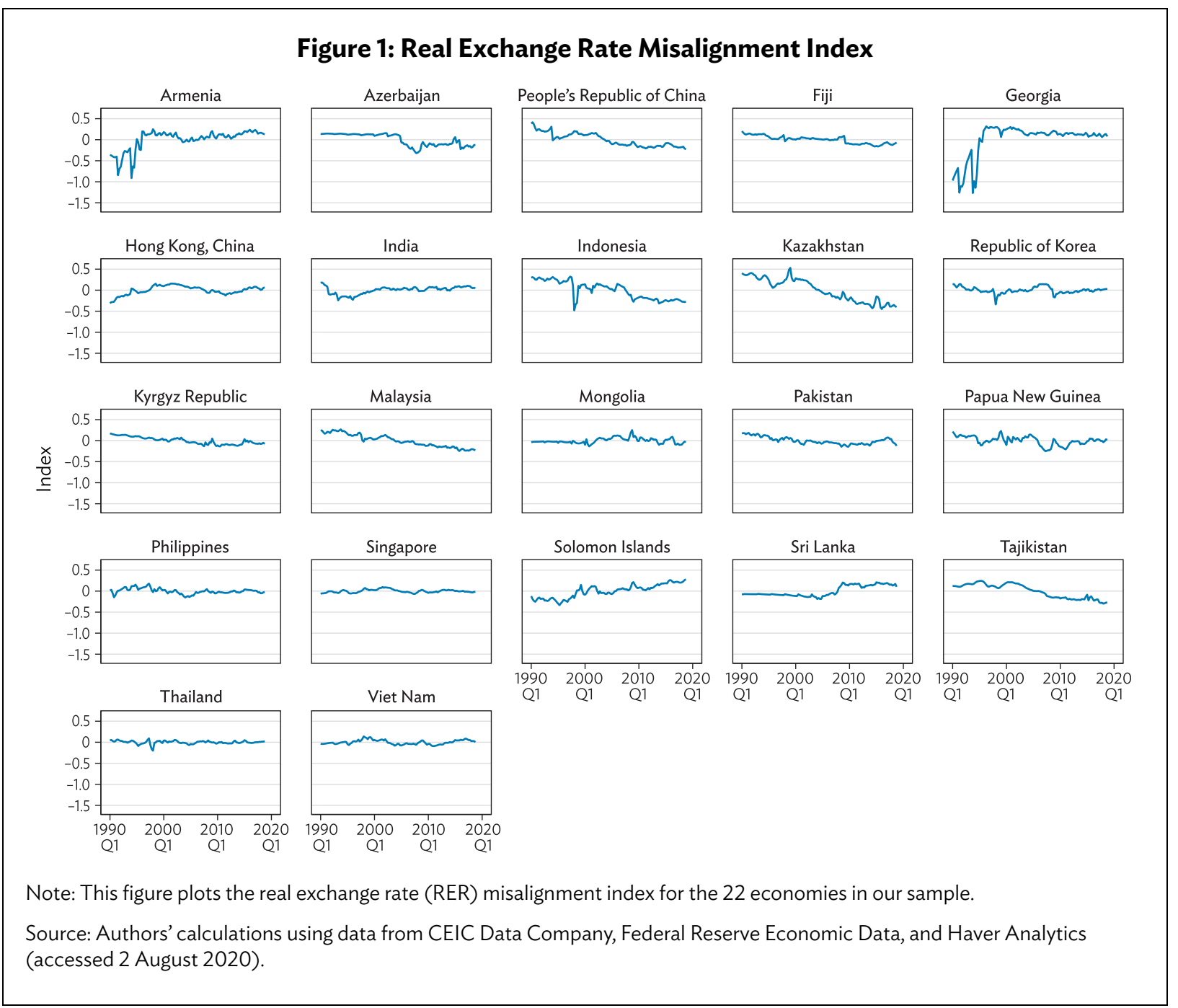


mid-2000s. Likewise, after the Global Financial Crisis, the Indonesian rupiah and the Malaysian ringgit were negatively misaligned since 2010 and their misalignment indices were slow to revert to zero.

Figure 2 plots the RER misalignment index over the business cycle (i.e., deviations of GDP per capita from the trend) for several economies in the sample. From this figure, RER misalignment varies

Figure 2: Real Exchange Rate Misalignment over the Business Cycle

(a) Hong Kong, China

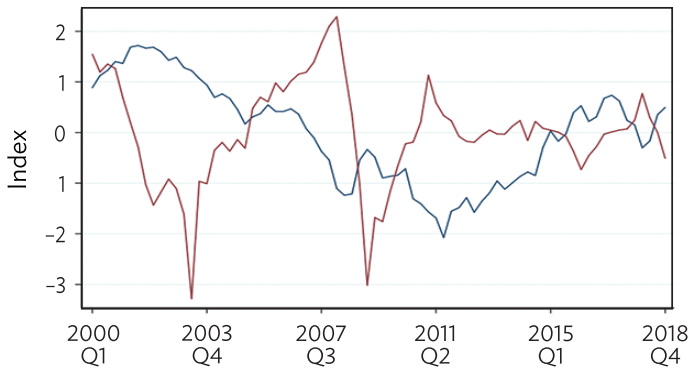

(c) Republic of Korea

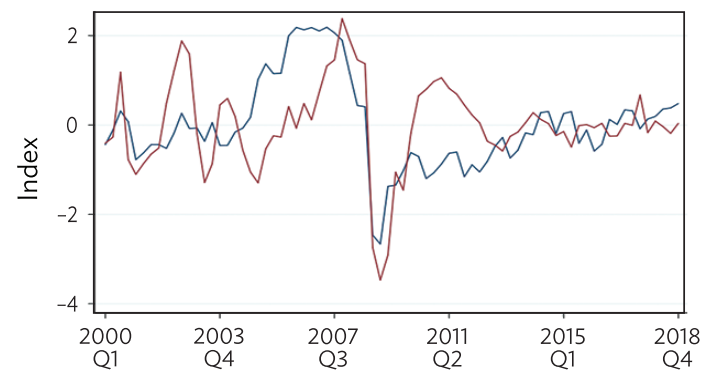

(e) Philippines

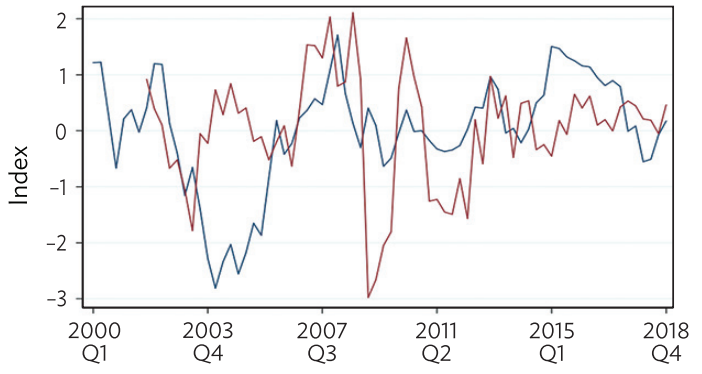

(g) Thailand

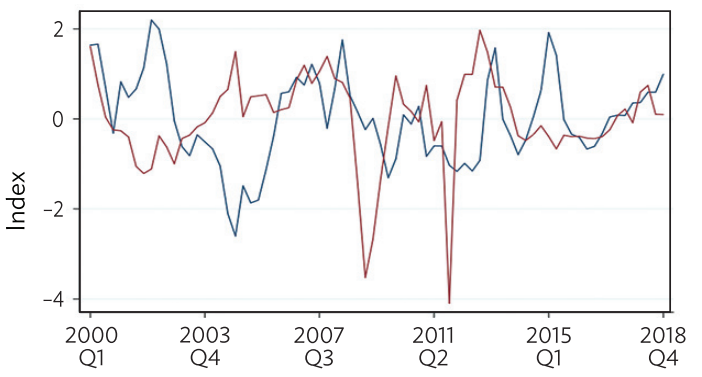

(b) Indonesia

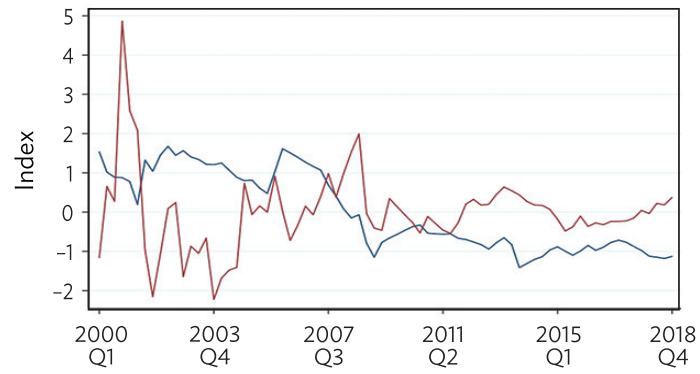

(d) Malaysia

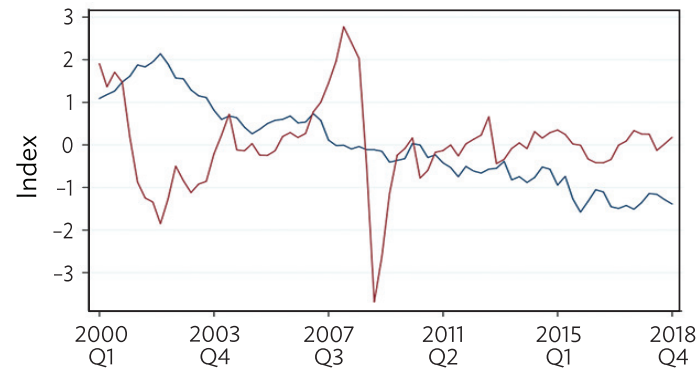

(f) Singapore

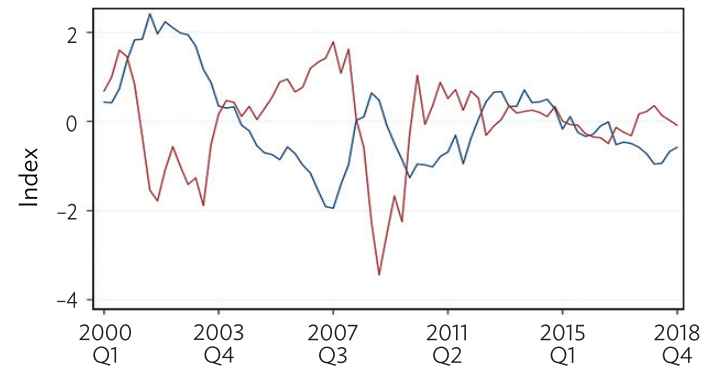

- Real exchange rate misalignment index, normalized - HP-based GDP growth cycle, normalized

Note: Both series are normalized with 0 mean and standard deviation equals to 1.

Source: Authors' calculations using data from CEIC Data Company, Federal Reserve Economic Data, and Haver Analytics (accessed 2 August 2020). 
over the business cycle with a lag. In Singapore, for example, the output gap had a significant turning point at Q4 2007, where it became positive to negative. Malaysia's RER was slightly positively misaligned in Q2 2010 but became negatively misaligned after that. A similar turning point can be observed for the output gap in Q4 2007 for Hong Kong, China, and this was followed by a worsening of the Hong Kong dollar in 2010.

\section{B. Comparison with Other Real Exchange Rate Misalignment Models}

RER models have been used by policy makers for assessing whether real exchange rates are in line with key economic fundamentals. ${ }^{13}$ A common approach of estimating RER misalignment is to first estimate the equilibrium exchange rate, and then construct the RER misalignment measure as the difference between the actual RER and the estimated equilibrium RER.

This is the approach we have taken here. As a comparison, we first look at how RER misalignment estimates compare with those estimated by Béreau, Villavicencio, and Mignon (2012) of Centre d'Études Prospectives et d'Informations Internationales (CEPII). Using a panel data based on selected economies (indexed by $I$ ) between 1980 and 2007 (indexed by $t$ ), Béreau, Villavicencio, and Mignon (2012) investigate the link between currency and economic growth and find that RER overvaluations undermine growth while undervaluations promote it. To compute RER misalignment, they first estimate an RER model with fixed effects where the log of the RER $\left(q_{i t}\right)$ is regressed on net foreign asset position, terms of trade, and relatively productivity. ${ }^{14}$ After estimating the model, the predicted values of the log of RER $\left(\hat{q}_{i t}\right)$ are used as the RER equilibrium values to compute the RER misalignment index, $m_{i t}=q_{i t}-\hat{q}_{i t}$.

Figure 3 compares our RER misalignment index (ADB) with the RER misalignment index constructed by CEPII for a sample of economies. While the RER misalignment series do not exactly coincide, they do share several similarities. For instance, both RER misalignment series may trend closely over certain periods. For Republic of Korea, for example, both the ADB and CEPII RER misalignment series started quite similarly in 1990, which represents an overvaluation. Both turned sharply negative in 1997-1998, which corresponds to the Asian Financial Crisis, when the economy lost significant portion of its foreign reserves due to an exchange rate crisis.

13 Throughout the paper, RER refers to real effective exchange rate.

14 Our model differs by using a larger set of external and internal fundamentals as regressors, which contain the variables used by Béreau, Villavicencio, and Mignon (2012). 
Figure 3: Real Exchange Rate Misalignment Index, CEPII and ADB

(a) Indonesia

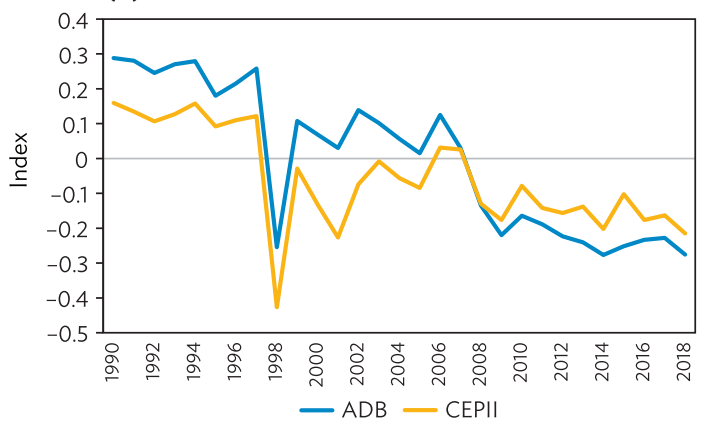

(c) Malaysia

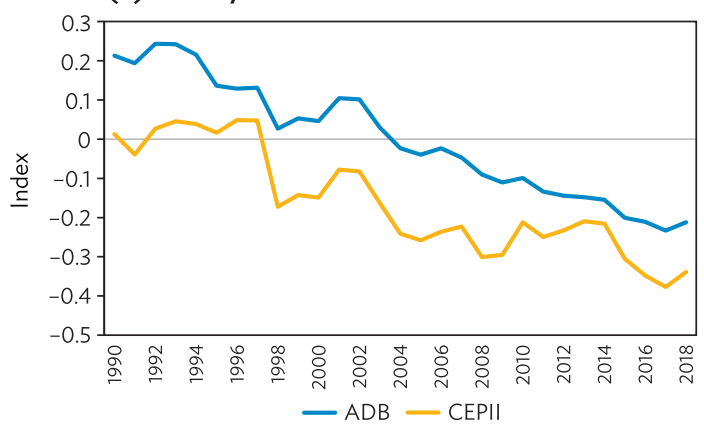

(e) Thailand

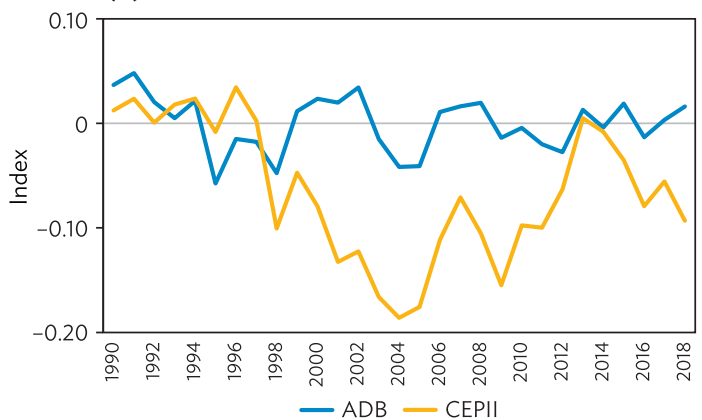

(b) Republic of Korea

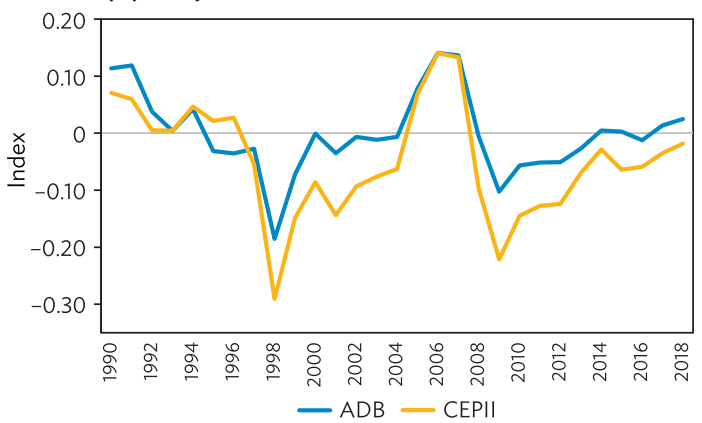

(d) People's Republic of China

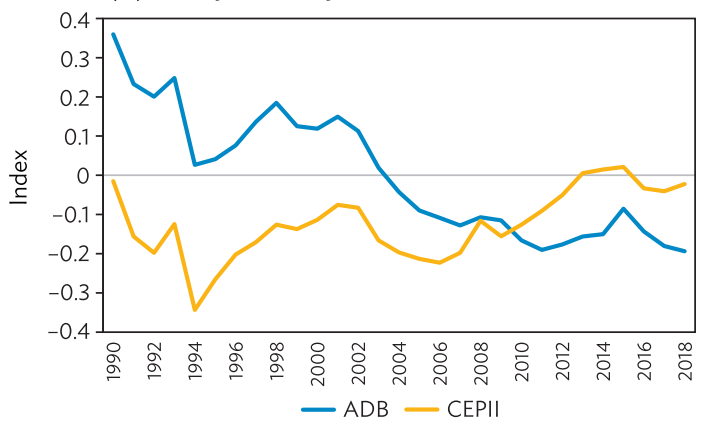

ADB = Asian Development Bank, CEPII = Centre D'Etudes Prospectives et d'Informations Internationales.

Source: Authors' calculations using data from CEIC Data Company, CEPII, Federal Reserve Economic Data, and Haver Analytics (accessed 2 August 2020).

Although the levels of the RER misalignment series can be different, the timing of their peak and troughs are quite similar. For example, while the levels of ADB's and CEPII's RER misalignment index are different in the early 2000s, both declined from 2002 to 2004, only to pick up from there. For Indonesia, both series show same major peaks and troughs. The significant depreciation of the Indonesian rupiah in 1998 during the Asian Financial Crisis is captured by both series, which show the RER misalignment index declining about 0.55 log points.

Next, we compare our RER misalignment index with the External Balance Assessment (EBA) framework from the International Monetary Fund (IMF). In its EBA framework, the IMF looks at the degree of RER misalignment to understand how much currency or price movements are necessary to 
correct excessive external imbalances. To estimate RER misalignment, or RER gap as it is referred to in Cubeddu et al. (2019), the IMF first estimates the current account gap (CAgap), then derive the RER gap (RERgap) from:

$$
R E R^{g a p}=\frac{C A^{g a p}}{\eta^{T B}}
$$

where $\eta^{T B}$ is the semi-elasticity of the nominal trade balance-to-GDP ratio. This parameter, in turn, is estimated from the decomposed equation:

$$
\eta^{T B}=\eta^{X S X}-\eta^{M S M}
$$

where $\eta^{X}$ and $\eta^{M}$ are the elasticities of nominal exports- and imports-to-GDP ratios with respect to RER, and $s^{X}$ and $s^{M}$ are the nominal shares of exports and imports with respect to GDP (Cubeddu et al. 2019).

Figure 4 compares our RER misalignment index with the ones computed based on the IMF EBA framework for the following: Indonesia, Malaysia, the PRC, the Republic of Korea, and Thailand. There are two RER misalignment estimates from the IMF. The series labeled "EBA" is sourced from IMF's EBA reports, which follow the methodology described in the above. The series labeled "EBA Staff" is sourced from the IMF's External Sector Reports, which follow the EBA approach but finetuned for economy-specific factors.

As the IMF's RER misalignment series are available in annual frequency, we report the unweighted annual average of the quarterly RER misalignment series that we have constructed. Interestingly, the two IMF series may not be similar to each other. For instance, for the Republic of Korea, the EBA series is significantly different from the EBA Staff series. However, despite the fact that the EBA series is constructed by backing out the RER misalignment from the current account gap, it turns out to be similar to the ADB series for the Republic of Korea. This can be seen between 2014 and 2018, where the EBA series tracks the ADB series very closely. Overall, the levels of the EBA, EBA Staff, and the $A D B$ series can be quite different from each other, but with similar turning points. 
Figure 4: Real Exchange Rate Misalignment Index, ADB and IMF

(a) Indonesia

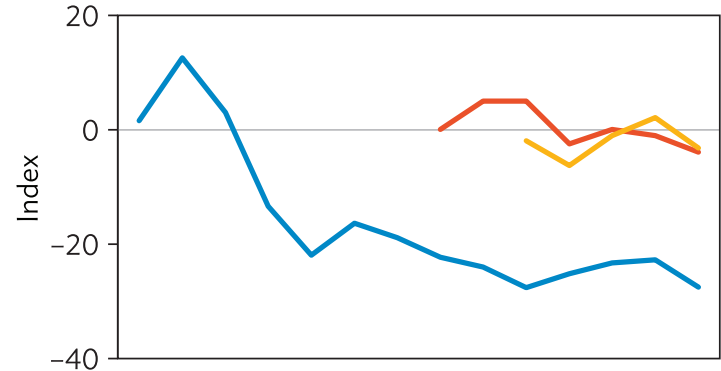

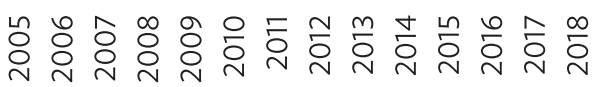

$$
\text { - EBA staff }-\mathrm{EBA}-\mathrm{ADB}
$$

(c) Malaysia

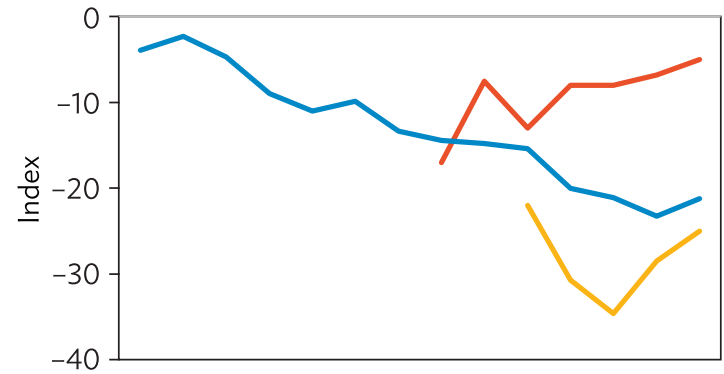

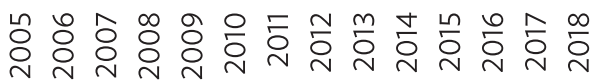

$$
\text { - EBA staff }- \text { EBA }-\mathrm{ADB}
$$

(e) Thailand

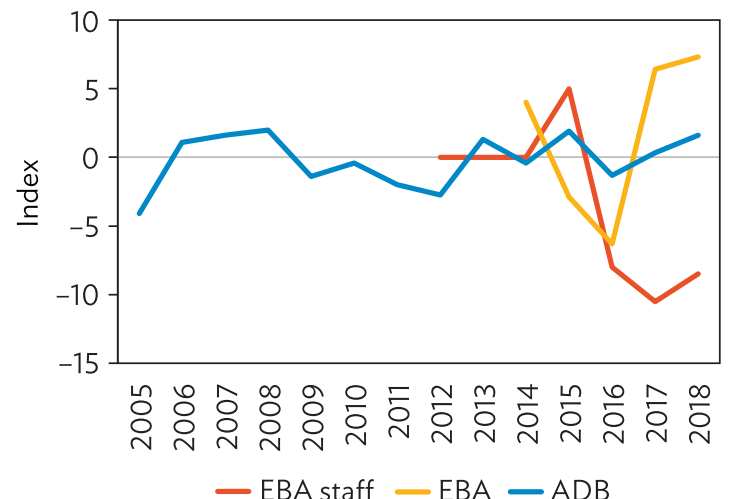

(b) Republic of Korea

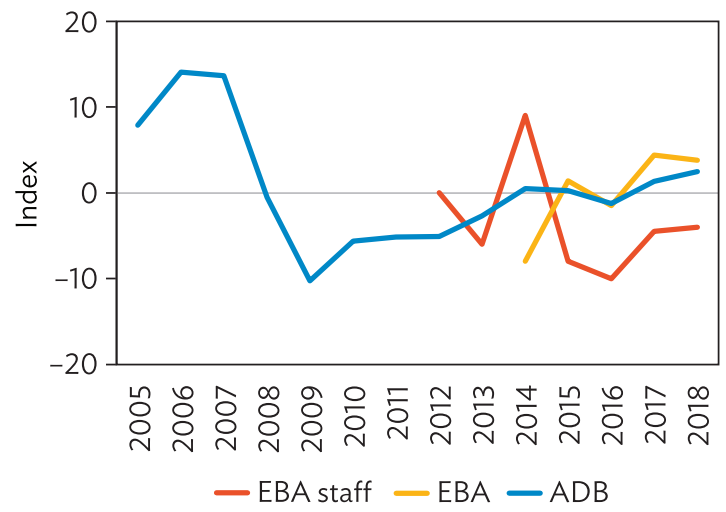

(d) People's Republic of China

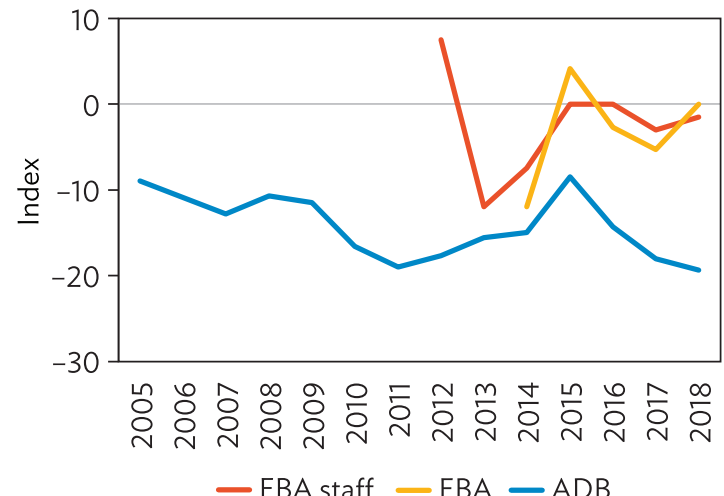

$\mathrm{ADB}=$ Asian Development Bank, EBA = External Balance Assessment, IMF = International Monetary Fund, PRC = People's Republic of China, RER = real exchange rate.

Note: EBA Staff is sourced from IMF's External Sector Reports. The methodology follows the EBA but fine-tuned for economy-specific factors. EBA is sourced from IMF's EBA reports. This report highlights real effective exchange rate gaps that are similar to RER misalignment only that it is computed based on the current account balance assessment. ADB is the unweighted annual average of the quarterly RER misalignment.

Source: Authors' calculations using data from CEIC Data Company, Federal Reserve Economic Data, Haver Analytics, and IMF EBA (accessed 2 August 2020). 


\section{METHODOLOGY}

\section{A. The Model}

We estimate the following panel VAR model:

$$
Y_{i t}=A_{0}+A_{1} Y_{i t-1}+\ldots+A_{p} Y_{i t-p}+u_{i}+v_{i t}
$$

where the $k \times 1$ vector $Y_{i t}$ contains the set of $k$ macroeconomic indicators, the $k \times k$ matrix $A_{i}$ contains the autoregressive coefficients, the $k \times 1$ vector $u_{i}$ represents economy $i$ 's fixed effects and $v_{i t}$ represents the idiosyncratic error term.

We estimate equation 4 with three lags, so that the dependent variable is linked with 1 year's worth of information. To remove the fixed effects, we employ the Anderson-Hsiao first-differenced transformation and use the Holtz-Eakin, Newey, and Rosen (1988) type instruments for the lagged first differenced dependent variables. ${ }^{15}$

To estimate equation 4, we employ a recursive scheme with CPI inflation ordered first, followed by output gap, interest rate, and RER misalignment. In a recursive scheme, shocks to the variable that are ordered prior are assumed to have contemporaneous effects on variables that are ordered later. As such, we are assuming that RER misalignment responds contemporaneously to shocks to CPI inflation, output gap, credit-to-output gap, interest rate, but shocks to RER misalignment only affects the other variables with a lag. The assumption that shocks to the RER or RER misalignment do not have contemporaneous effects has precedence (see, for example, Houssa, Mohimont, and Otrok 2015 and Comunale 2021). As a remark, because data on credit-to-output gap are available for eight economies only, we will omit it in the baseline and introduce it in our robustness checks.

\section{B. Preliminary Diagnostics}

Before we estimate equation 4, we first check that our variables are stationary. To do so, we need to verify if cross-sectional dependence is present. In principle, geographically proximate economies could be correlated through economic and financial cooperation, trade, or similarities in policies and thus, it is typical for economies within a specific region (like Asia and the Pacific) to be cross-sectionally dependent. If so, we will have to implement panel unit root tests that account for cross-sectional dependence (Pesaran 2007).

To test for cross-sectional dependence, we implement the cross-sectional dependence (CD) test of Pesaran (2007). This test examines if there is pair-wise correlation (i.e., CD) between the residuals of two cross-sectional units that are generated from unit-by-unit ordinary least squares (OLS) regressions. ${ }^{16}$ The null hypothesis of the CD test is cross-sectional independence and rejection of the test suggests that CD is present. In Table 3, we compute the CD test statistic for each variable. We have evidence that CPI inflation, output gap, interest rate, and RER misalignment are cross-

15 Holtz-Eakin, Newey, and Rosen (1988) constructed an instrument matrix using the second lag of the dependent variable, with one instrument pertaining to each time period.

16 The unit in this case is economy. 
sectionally dependent ( $p$-value of less than 0.001). The evidence that the credit-to-output gap is cross-sectionally dependent is weaker ( $p$-value of 0.07 ).

Table 3: Cross-Sectional Dependence Test

\begin{tabular}{lcc}
\hline Variable & CD-test & P-value \\
\hline cpi inf & 24.1 & 0.000 \\
output gap & 37.185 & 0.000 \\
crgdp gap & -1.812 & 0.070 \\
irate & 24.895 & 0.000 \\
misalign & 10.377 & 0.000 \\
\hline
\end{tabular}

CD-test $=$ cross-sectional dependence test statistic, $\mathrm{cpi}$ inf $=$ consumer price index inflation, crgdp gap $=$ credit-to-gross domestic product gap, irate = interest rate, misalign = real exchange rate misalignment.

Note: The null hypothesis of the CD-test is cross-sectional independence.

Source: Authors' calculations using data from CEIC Data Company, Federal Reserve Economic Data, and Haver Analytics (accessed 2 August 2020).

As there is evidence of cross-sectional dependence, we employ the augmented Dickey-Fuller (ADF) test for cross-sectionally dependent data, called the CADF test proposed by Pesaran (2007), to test for stationarity for each variable (based on the null hypothesis that unit root is present). The results, reported in Table 4, suggest that CPI inflation, output gap, credit-to-output gap, and RER misalignment are stationary at the $1 \%$ level of significance. The null hypothesis of non-stationarity can also be rejected for short-term interest rate at the $10 \%$ level of significance. Therefore, it is reasonable to use these variables in levels for our VAR, as expressed in equation 4.

Table 4: Unit Root Test with Cross-Sectional Dependence

\begin{tabular}{lcc}
\hline Variable & t-test & P-value \\
\hline cpi inf & -10.544 & 0.000 \\
output gap & -19.418 & 0.000 \\
crgdp gap & -13.592 & 0.000 \\
irate & -1.416 & 0.078 \\
misalign & -2.365 & 0.002 \\
\hline
\end{tabular}

$\mathrm{cpi}$ inf = consumer price index inflation, $\mathrm{crgdp}$ gap = credit-to-gross domestic product gap, irate $=$ interest rate, misalign $=$ real exchange rate misalignment.

Note: The Augmented Dickey-Fuller test with cross-sectional dependence (CADF) test is implemented. The null hypothesis of the CADF test is non-stationarity.

Source: Authors' calculations using data from CEIC Data Company, Federal Reserve Economic Data, and Haver Analytics (accessed 2 August 2020). 


\section{RESULTS}

\section{A. Baseline Results}

We estimate equation 4 with 3 lags and plot the impulse response functions in Figure 5 for 30 quarters following a one-standard deviation orthogonalized shock to CPI inflation, output gap, short-term interest rate, and RER misalignment, respectively. Together with each impulse response, we also report the one-standard deviation confidence band.

Response of real exchange rate misalignment to the other shocks. We first discuss the response of RER misalignment to CPI inflation, output gap, and interest rate shocks based on the impulse responses plotted by the subfigures in the first column of Figure 5.

Figure 5: Baseline Impulse Response Functions
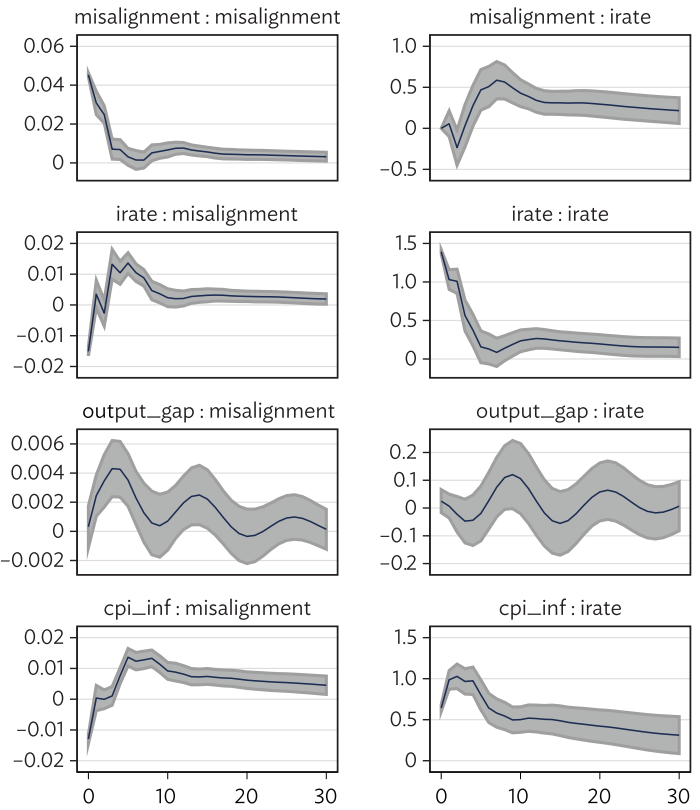

output_gap : irate
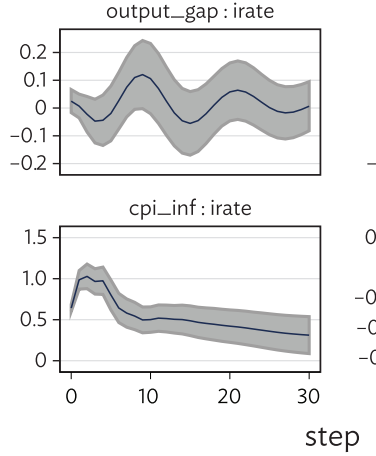

$68 \% \mathrm{Cl}$
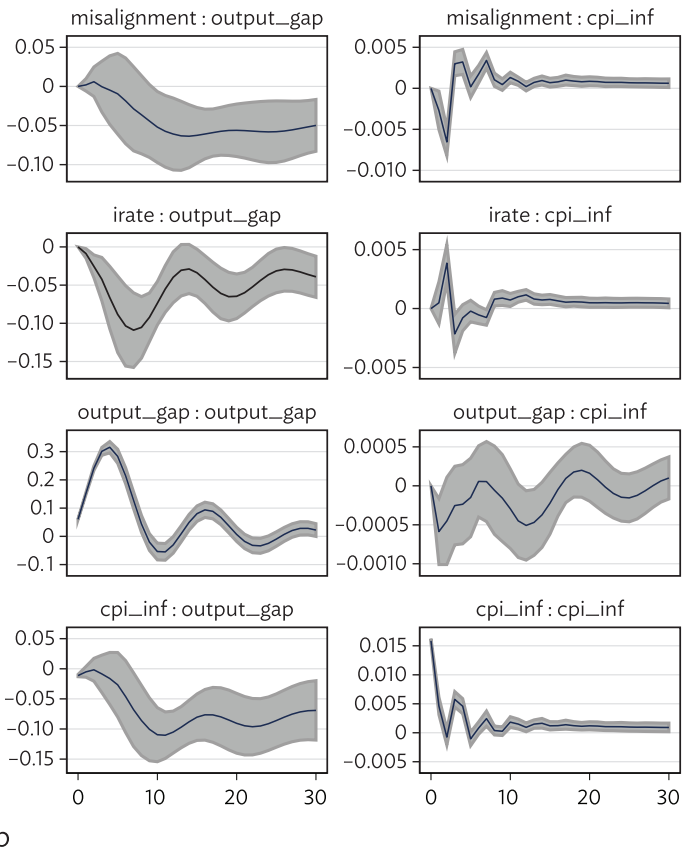

Orthogonalized IRF

impulse : response

$\mathrm{Cl}=$ confidence interval, $\mathrm{cpi}$ _inf = consumer price index inflation, irate = interest rate, IRF = impulse response function, misalignment $=$ real exchange rate misalignment.

Note: The vector autoregression is estimated by first eliminating fixed effects using Anderson and Hsiao (1982) and then instrumenting with the Holtz-Eakin, Newey, and Rosen (1988) instruments.

Source: Authors' calculations using data from CEIC Data Company, Federal Reserve Economic Data, and Haver Analytics (accessed 2 August 2020); Theodore W. Anderson, and Cheng Hsiao. 1982. "Formulation and Estimation of Dynamic Models Using Panel Data." Journal of Econometrics 18 (1): 47-82; Douglas Holtz-Eakin, Whitney Newey, and Harvey S. Rosen. 1988. “Estimating Vector Autoregressions with Panel Data." Econometrica 56 (6): 1371-95. 
RER misalignment responds negatively to a CPI inflation shock on impact but becomes positive several quarters later. For example, immediately after a one-standard deviation orthogonalized CPI inflation shock, CPI inflation increased by 1.5 percentage points while RER misalignment fell by 0.01 log point on impact, which is a $1 \%$ decrease in the RER relative to its equilibrium. After its initial response, $\mathrm{CPI}$ inflation converged toward zero after 4 quarters. For the RER, it became overvalued by about $1.2 \%$ after 5 quarters before the misalignment decayed towards zero.

RER misalignment responds positively but weakly to a shock to output gap. For instance, following a one-standard deviation orthogonalized shock, output gap immediately increased by 0.9 , or by one-standard deviation. However, RER misalignment was hardly affected on impact, and after 5 quarters, it only topped at 0.004 , or about $0.4 \%$.

RER misalignment responds negatively to an interest rate shock on impact. However, it turns positive several quarters later, which is similar to how it responded to a CPI inflation shock. Following a one-standard deviation orthogonalized shock, the interest rate increased by more than 1 percentage point while RER misalignment decreased by about 0.01 log point (or about 1\%) on impact. However, after 4 quarters, RER misalignment turned positive and topped at about 0.012 log point before converging towards zero.

Overall, the impulse responses suggest that RER misalignment could be driven by fluctuations in CPI inflation and interest rate, but not output gap. Furthermore, the convergence of RER misalignment toward zero is slow. For a CPI inflation shock, it took RER misalignment nearly 30 quarters to revert to zero. This suggests that once the RER is misaligned, the misalignment could remain persistent. This is consistent with what we have observed for some economies in our sample where the misalignment of their RERs have been slow to decay.

Response of other variables to real exchange rate misalignment shock. We examine the impact that RER misalignment shocks may have on CPI inflation, output gap, and interest rate. The responses of the latter variables to a one-standard deviation orthogonalized RER misalignment shock are plotted by the subfigures in the first row of Figure 5.

Just as RER misalignment responds to CPI inflation shock, the converse is true as well. On impact, RER misalignment increased by about $4 \%$ following its own shock. Within three quarters, CPI inflation fell by more than 0.5 percentage points. It then increased to 0.4 percentage points at its peak 2 quarters later, before converging back to zero.

The RER misalignment shock has a negative but slow impact on the output gap. For instance, following the RER misalignment shock, output gap fell slowly over 10 quarters and bottomed out at -0.07 , which corresponds to a $7 \%$ decline in output relative to its trend. ${ }^{17}$ Interestingly, among all the variables, output gap is the slowest to recover from an RER misalignment shock. Therefore, while misalignment only has a weak impact on output gap, its impact on the output gap can be highly persistent over time.

RER misalignment affects interest rate like how it affects CPI inflation. Following an RER misalignment shock, interest rate declined by about 30 basis points after 2 quarters. After which, its impulse response turned positive to peak at 60 basis points at the 8 th quarter before declining toward the steady state.

17 The translation from -0.07 to $-7 \%$ comes from the fact the cyclical component of output is based on the log of output, and that -0.07 approximately reflects output being $0.07 \log$ point below its trend. 
In sum, RER misalignment shocks affect CPI inflation, interest rate, and output gap. The main difference is that CPI inflation and interest rate converge quickly toward zero following an RER misalignment shock. However, for the output gap, its recovery to zero is very slow. This suggests that while the impact of RER misalignment on output may not be large, it may potentially be long-lasting.

\section{B. Robustness Checks}

Reverse ordering. Our first robustness check examines how sensitive our baseline impulse responses are to the order we impose on the variables. To take an extreme position, we completely reverse the order of the variables in the VAR imposed by the baseline, so that RER misalignment is ordered first, followed by interest rate, output gap, and finally CPI inflation. The impulse responses, which are plotted in Figure 6, are similar to those reported in the baseline as shown in Figure 5. For instance, the last row of Figure 6 plots the impulse response of each variable to an RER misalignment shock. Here, we can see that the impulse responses of CPI inflation and interest rate have a similar trajectory as the baseline impulse responses, where CPI inflation and interest rate fell on impact before turning positive.

Figure 6: Reverse Ordering of Variables in the Baseline Model
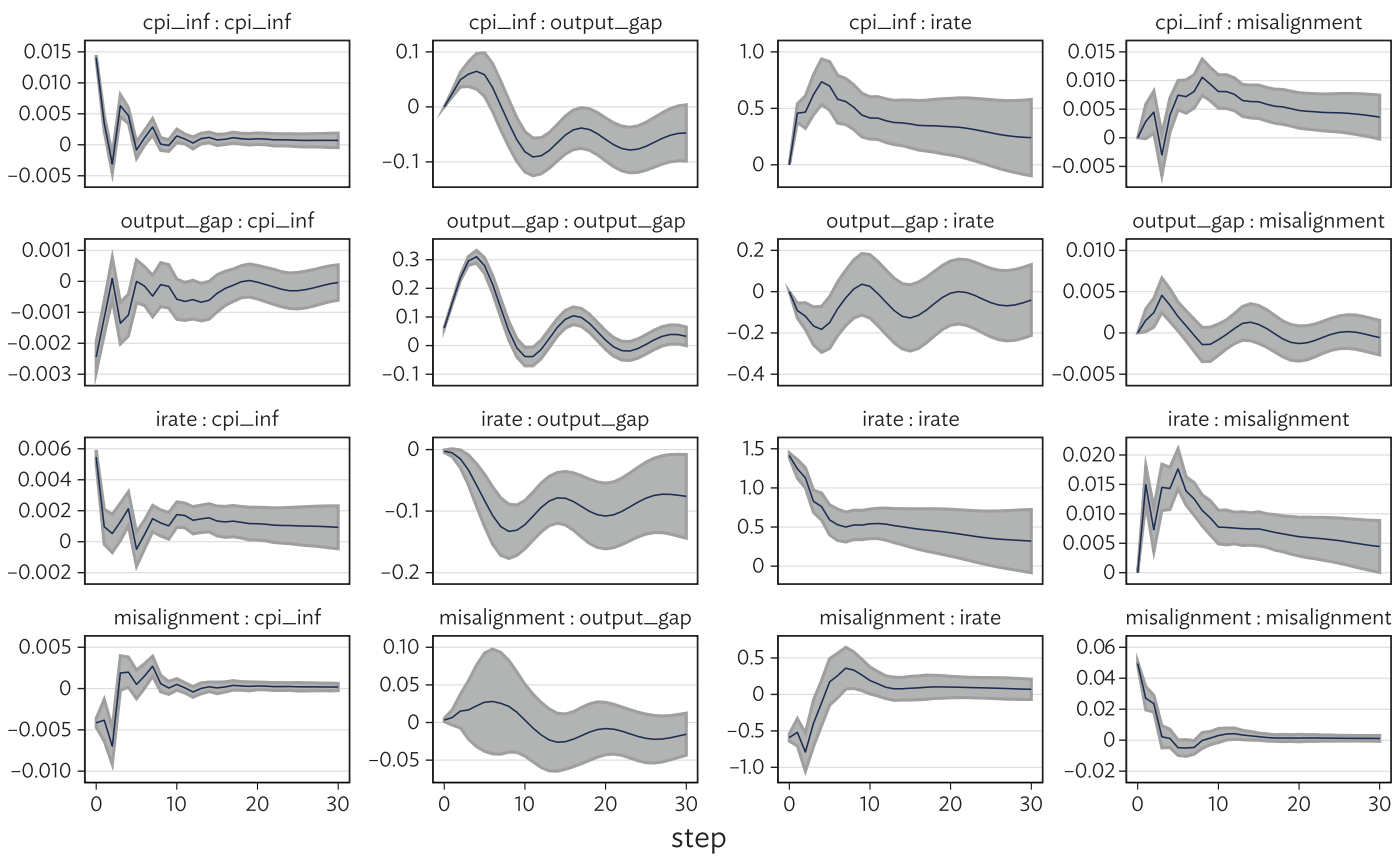

$68 \% \mathrm{Cl}$

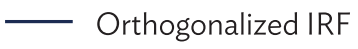

impulse : response

$\mathrm{Cl}=$ confidence interval, $\mathrm{cpi} \_$inf $=$consumer price index inflation, irate = interest rate, IRF = impulse response function, misalignment $=$ real exchange rate misalignment.

Note: The vector autoregression is estimated by first eliminating fixed effects using Anderson and Hsiao (1982) and then instrumenting with the Holtz-Eakin, Newey, and Rosen (1988) instruments.

Source: Authors' calculations using data from CEIC Data Company, Federal Reserve Economic Data, and Haver Analytics (accessed 2 August 2020); Theodore W. Anderson, and Cheng Hsiao. 1982. "Formulation and Estimation of Dynamic Models Using Panel Data.” Journal of Econometrics 18 (1): 47-82; Douglas Holtz-Eakin, Whitney Newey, and Harvey S. Rosen. 1988.

“Estimating Vector Autoregressions with Panel Data." Econometrica 56 (6): 1371-95. 
Similarly, like the baseline, the impulse response of the output gap is statistically insignificant. This suggests that the baseline results are not driven by how variables in the VAR are ordered.

Misalignment of "volatile" and "stable" economies. We investigate if the stability of the RER matters for how the variables respond to different stimulus. To do so, we divide our sample economies into two groups: (i) misalignment-"volatile" economies and (ii) misalignment-"stable" economies. Economies are defined as misalignment-volatile if their misalignment standard deviation exceeds 0.1 (i.e., 10\%) during the sample period. Included in this subsample are 9 economies: Armenia; Azerbaijan; Georgia; Hong Kong, China; Indonesia; Kazakhstan; Malaysia; the PRC; and Sri Lanka. The remaining economies in the sample are classified as misalignment-stable. ${ }^{18}$

Figures 7 and 8 compare the misalignment-volatile economies with the misalignment-stable economies. The misalignment-volatile economies have impulse responses that are similar to the baseline with narrower confidence bands, where for instance, Figure 7 shows that RER misalignment shocks have a clear impact on CPI inflation and interest rate but a weak negative impact on output gap.

\section{Figure 7: Impulse Responses for Economies with Volatile Real Exchange Rate}

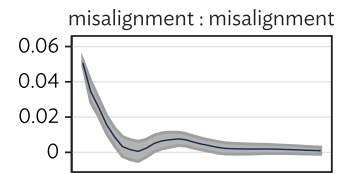

irate : misalignment

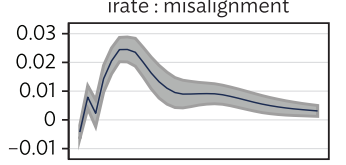

output_gap : misalignment

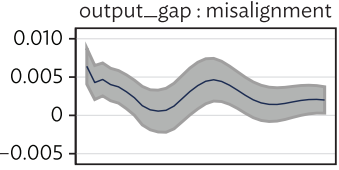

cpi_inf : misalignment
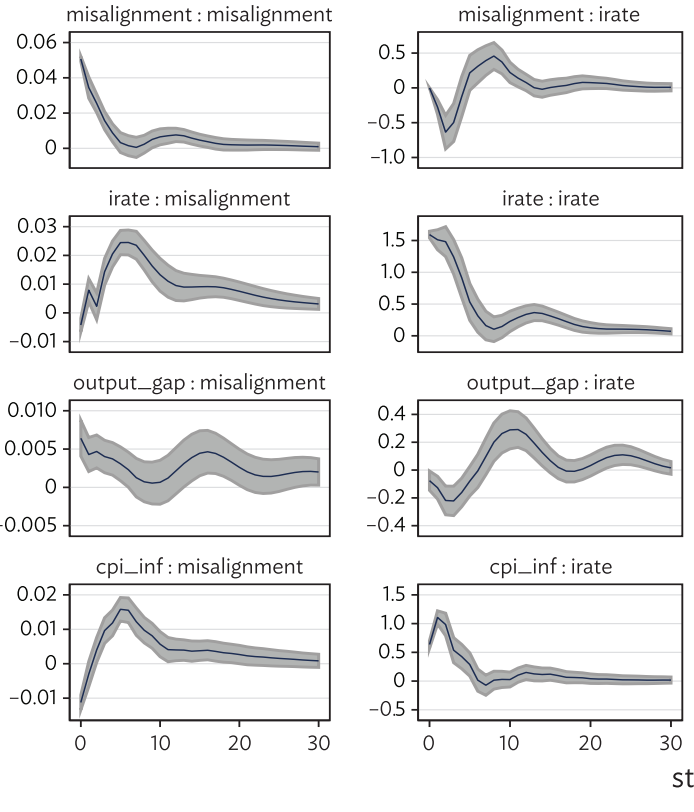

irate : irate

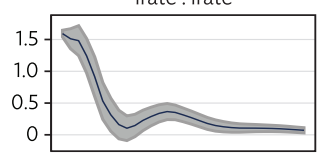

output_gap : irate

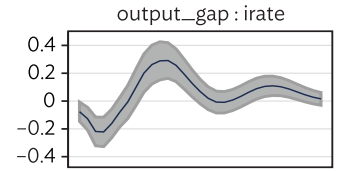

cpi_inf: irate
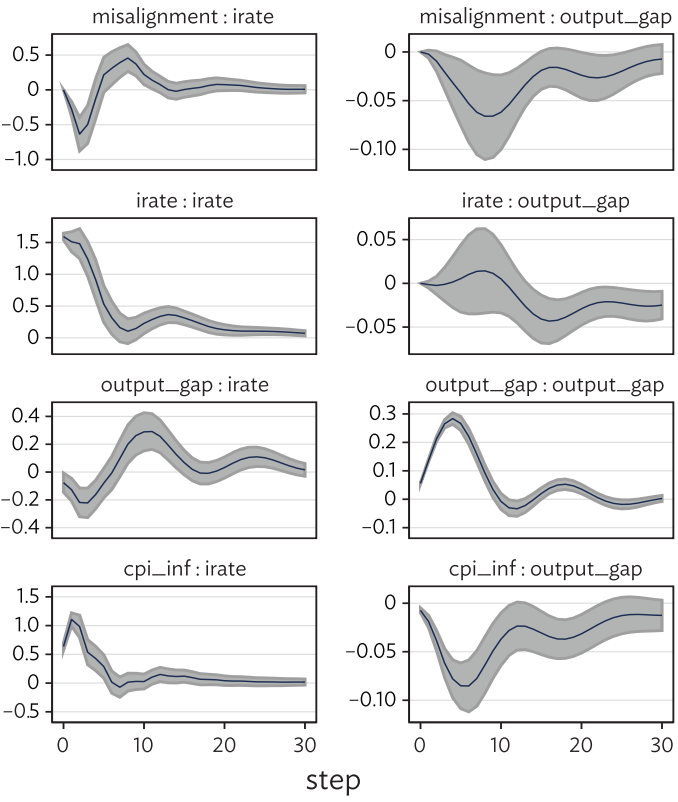

irate : output_gap
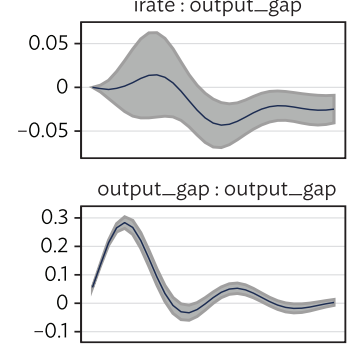

cpi_inf: output_gap

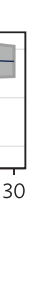

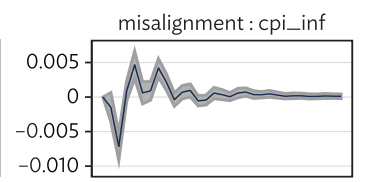
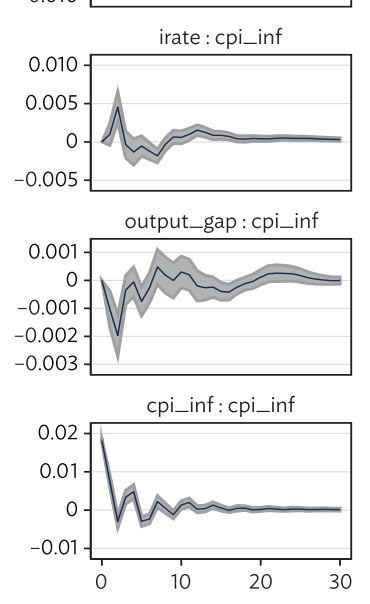

impulse : response

$\mathrm{Cl}=$ confidence interval, $\mathrm{cpi}$ _inf = consumer price index inflation, irate = interest rate, IRF = impulse response function, misalignment $=$ real exchange rate misalignment.

Note: The vector autoregression is estimated by first eliminating fixed effects using Anderson and Hsiao (1982) and then instrumenting with the Holtz-Eakin, Newey, and Rosen (1988) instruments.

Source: Authors' calculations using data from CEIC Data Company, Federal Reserve Economic Data, and Haver Analytics (accessed 2 August 2020); Theodore W. Anderson, and Cheng Hsiao. 1982. "Formulation and Estimation of Dynamic Models Using Panel Data." Journal of Econometrics 18 (1): 47-82; Douglas Holtz-Eakin, Whitney Newey, and Harvey S. Rosen. 1988.

"Estimating Vector Autoregressions with Panel Data." Econometrica 56 (6): 1371-95.

18 Not all 22 economies are contained in either group. Because interest rate data are missing for five economies, they were excluded from the exercise. 
Figure 8: Impulse Responses for Economies with Stable Real Exchange Rate
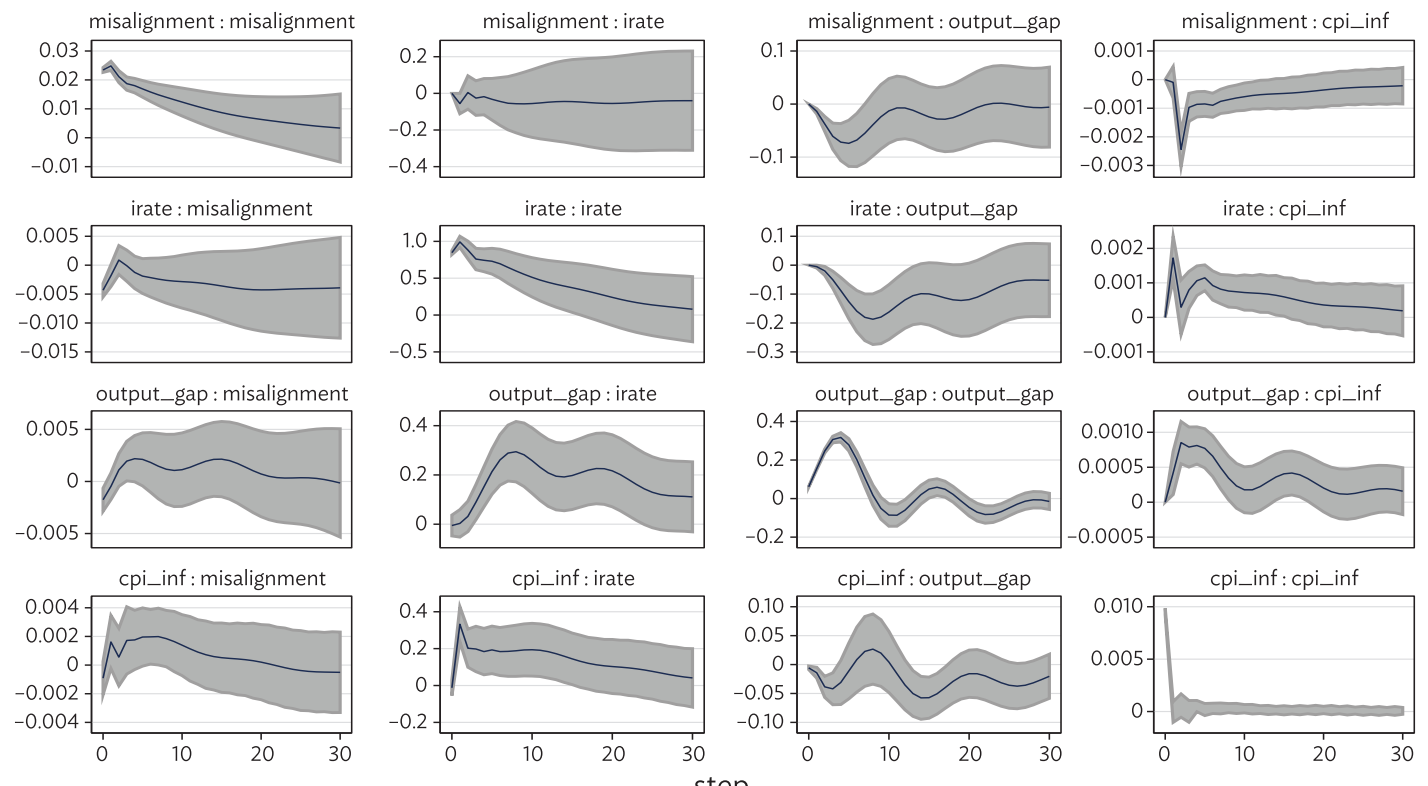

$68 \% \mathrm{Cl}$

Orthogonalized IRF

impulse : response

$\mathrm{Cl}=$ confidence interval, $\mathrm{cpi} \_$inf $=$consumer price index inflation, irate = interest rate, IRF = impulse response function, misalignment $=$ real exchange rate misalignment.

Note: The vector autoregression is estimated by first eliminating fixed effects using Anderson and Hsiao (1982) and then instrumenting with the Holtz-Eakin, Newey, and Rosen (1988) instruments.

Source: Authors' calculations using data from CEIC Data Company, Federal Reserve Economic Data, and Haver Analytics (accessed 2 August 2020); Theodore W. Anderson, and Cheng Hsiao. 1982. "Formulation and Estimation of Dynamic Models Using Panel Data." Journal of Econometrics 18 (1): 47-82; Douglas Holtz-Eakin, Whitney Newey, and Harvey S. Rosen. 1988.

“Estimating Vector Autoregressions with Panel Data." Econometrica 56 (6): 1371-95.

By contrast, the misalignment-stable economies have impulse responses that are generally much weaker with much larger confidence bands. For instance, Figure 8 shows that the interest rate from the misalignment stable economies did not have any significant response to RER misalignment shock. The one-standard deviation band was also very wide, suggesting that RER misalignment did not have any impact on the interest rate. Compared to the misalignment-volatile economies shown in Figure 7, the interest rate fell by more than 0.5 percentage points following an RER misalignment shock. After which, it reverted to reach the peak of about 0.5 percentage points before converging to zero.

Since the baseline panel VAR employs data for both misalignment-stable and misalignmentvolatile economies, the results here suggest that the baseline estimates are driven by the misalignment-volatile economies, as the impulse responses from these economies, not the misalignment-stable economies, are similar to the baseline.

Forward orthogonal deviation transformation. Besides the first-differenced transformation, there are other approaches of dealing with unobserved heterogeneity. As a robustness check, we employ forward orthogonal deviation transformations, which involves differencing the original time 
series with their respective forward averages, to remove the fixed effects. ${ }^{19}$ The main advantage of this approach is that it preserves more instruments and allows the first lag in levels to be used as instruments for the transformed variables. This is unlike the Anderson-Hsiao approach where only the second and further lags in levels of the transformed variables can be used as instruments.

The impulse responses, where the data are transformed using forward orthogonal deviation, are plotted in Figure 9. Comparing the results with the baseline, we find that the method by which we deal with fixed effects (i.e., first differencing or forward orthogonal deviations) does not matter much for the impulse responses. For example, RER misalignment responded to CPI inflation and interest rate shocks in the same way as RER misalignment did in the baseline. The responses of the other variables following an effect of RER misalignment shock were similar as well. In fact, the confidence bands of the impulse responses based on the forward orthogonal deviation transformation are narrower. This suggests that our results are not dependent on the differencing approach chosen to eliminate the fixed effect.

Figure 9: Impulse Response Based on Forward Orthogonal Deviation Transformation
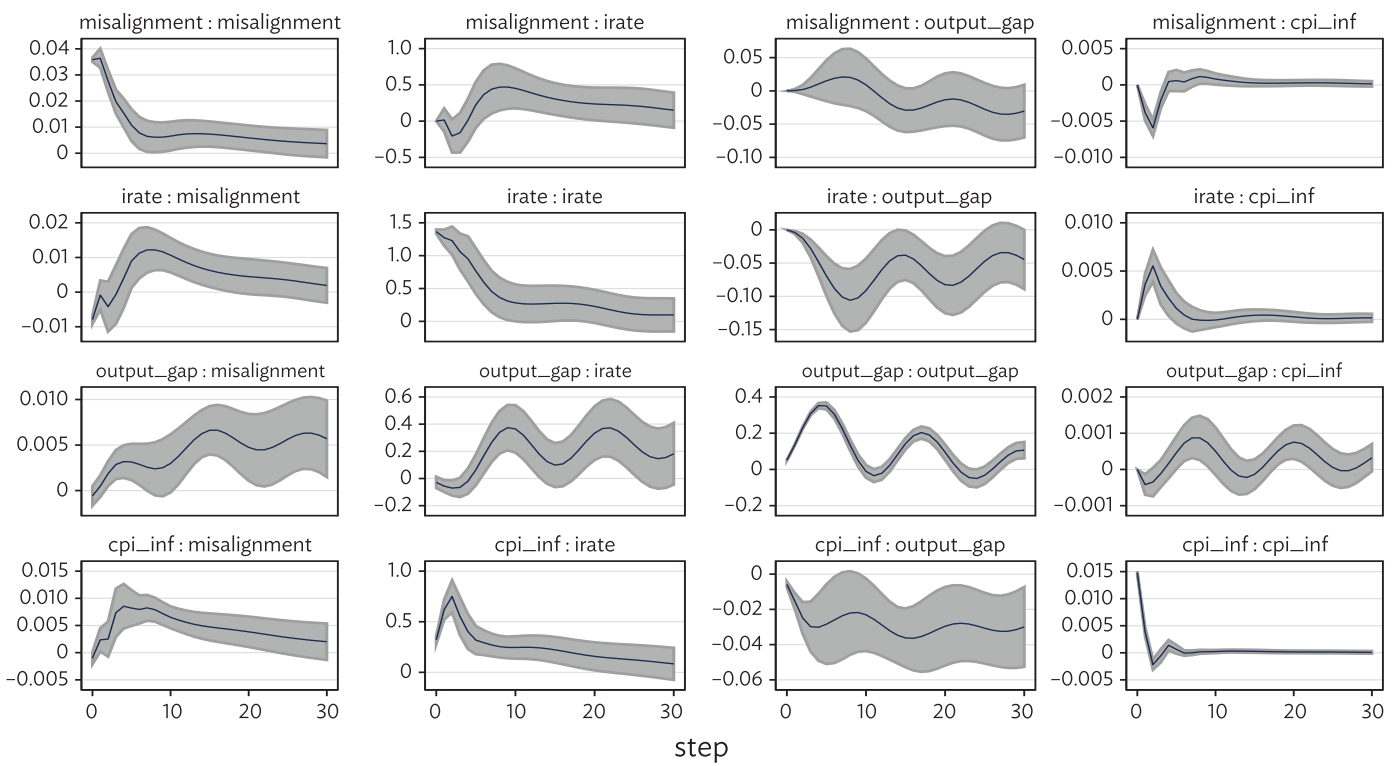

$68 \% \mathrm{Cl}$

Orthogonalized IRF

impulse : response

$\mathrm{Cl}=$ confidence interval, $\mathrm{cpi} \_$inf = consumer price index inflation, irate = interest rate, IRF = impulse response function, misalignment $=$ real exchange rate misalignment.

Note: The vector autoregression is estimated using forward orthogonal deviation transformation to eliminate fixed effects.

Source: Authors' calculations using data from CEIC Data Company, Federal Reserve Economic Data, and Haver Analytics (accessed 2 August 2020).

19 For example, to transform the $k$ th variable in $Y_{i t}$ (denoted by $Y_{i t}^{k}$ ) using forward orthogonal deviation, we first construct the difference $Y_{i t}^{k}=\gamma_{i t}\left(Y_{i t}^{k}-\overline{Y_{i t}^{k}}\right)$, where $\overline{Y_{t t}^{k}}=\sum_{s=t+1}^{T_{i}} Y_{i t}^{k}$ is the forward mean, $T_{i}^{k}$ is the end of the sample period for economy $i$ 's variable $k$, and $\gamma_{i t}=\sqrt{(T i-t) /(T i-t+1)}$. 
Excluding interest rate. We do not have data on the interest rates for five economies: Fiji, the Kyrgyz Republic, Papua New Guinea, Solomon Islands, and Tajikistan. ${ }^{20}$ To incorporate these economies into our panel analysis, we must exclude the interest rate from the VAR.

In Figure 10, we plot the impulse responses based on the ordering of CPI inflation, output gap, and RER misalignment. Here, we can see that a shock to CPI inflation had resulted in an RER overvaluation over 5 quarters before the misalignment recovered towards zero. We also find that a shock to output gap had led to a slight RER undervaluation, which eventually became an overvaluation after 6 quarters. Additionally, in response to an RER misalignment shock, we can see a more pronounced decline in output gap, suggesting that RER overvaluation had led to a decrease in output. The RER misalignment shock also had caused CPI inflation to decrease in the first few years before the latter recovered toward zero. These impulse responses are mostly similar to the responses documented in the baseline case.

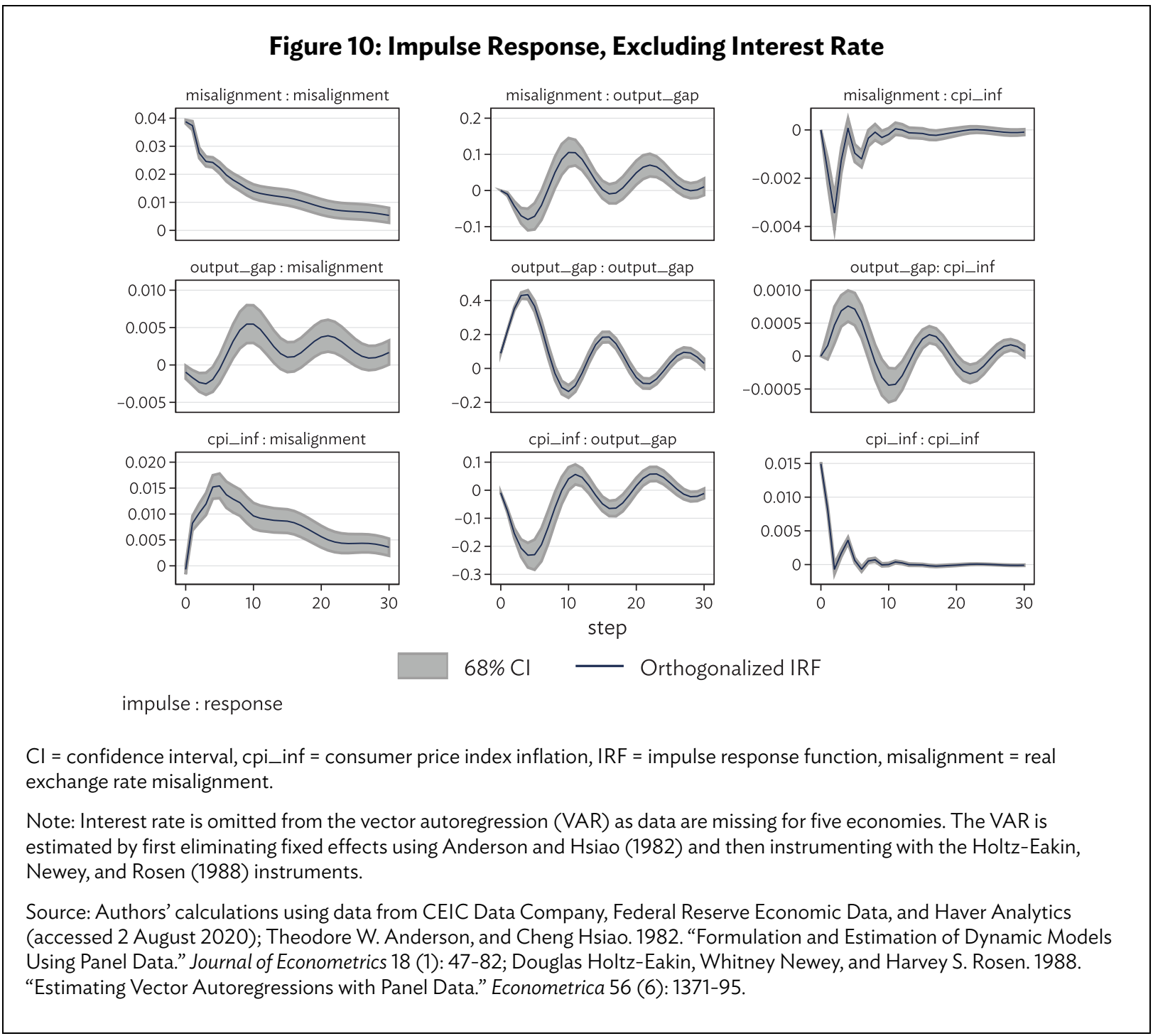

20 Data on output gap and CPI inflation are available for all economies in our sample. 
Credit-to-gross domestic product gap. In our baseline regression, we did not employ creditto-GDP gap as data were unavailable for many economies. In this robustness check, we replace output gap with credit-to-GDP gap. The economies for which credit-to-output gap data are available are Hong Kong, China; Indonesia; Malaysia, the Philippines, the Republic of Korea; Singapore; Taipei,China; and Thailand.

Figure 11 shows that there is a clear decline in the credit-to-GDP gap following an RER misalignment shock, as opposed to a weak decline observed for the output gap. The size of the decline is large: following a one-standard deviation orthogonalized shock to RER misalignment, RER misalignment increased by slightly more than $2 \%$ on impact, and then converged slowly toward zero.

Figure 11: Impulse Response, Credit-to-GDP Gap
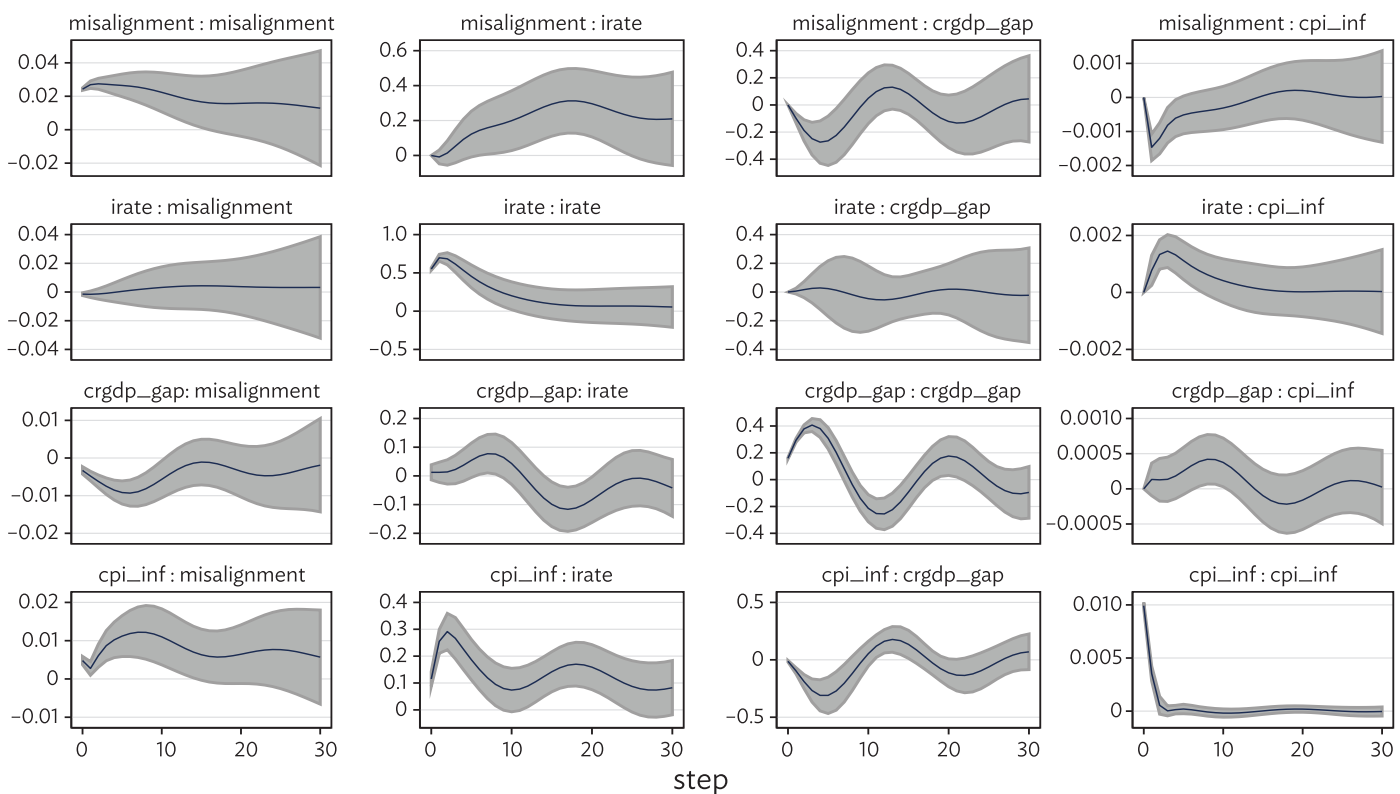

$68 \% \mathrm{Cl}$

Orthogonalized IRF

impulse : response

$\mathrm{Cl}=$ confidence interval, $\mathrm{cpi} \_$inf $=$consumer price index inflation, $\mathrm{crgdp}$ gap = credit-to-gross domestic product gap, irate $=$ interest rate, $I R F=$ impulse response function, misalignment $=$ real exchange rate misalignment.

Source: Authors' calculations using data from CEIC Data Company, Federal Reserve Economic Data, and Haver Analytics (accessed 2 August 2020); Theodore W. Anderson, and Cheng Hsiao. 1982. "Formulation and Estimation of Dynamic Models Using Panel Data.” Journal of Econometrics 18 (1): 47-82; Douglas Holtz-Eakin, Whitney Newey, and Harvey S. Rosen. 1988. “Estimating Vector Autoregressions with Panel Data." Econometrica 56 (6): 1371-95.

However, by the 5 th quarter, the credit-to-output gap had declined by 0.3 log point, or about $25 \%$, which implies that credit-to-output gap is sensitive to RER misalignment shocks. Moreover, given that output gap is only mildly sensitive to RER misalignment, this suggests that RER misalignment has a substantial influence on credit fluctuations. 


\section{Variance Decomposition}

Table 5 reports the variance decomposition based on a forecast 10 quarters. Based on these estimates, nearly $20 \%$ of the variation in CPI inflation and about $12 \%$ of the variation in interest rate can be explained by RER misalignment. However, RER misalignment contributes little to the variation in output gap.

In turn, over $17 \%$ of the variation in RER misalignment can be explained by CPI inflation, $16 \%$ by interest rate, and only $1 \%$ by output gap. Therefore, there is evidence that misalignment matters for $\mathrm{CPI}$ inflation and interest rates over the business cycle.

Table 5: Variance Decomposition

\begin{tabular}{lcccc}
\hline & \multicolumn{3}{c}{ Impulse Variable } \\
\cline { 2 - 5 } Response Variable & CPI Inflation & Output Gap & Interest Rate & Misalignment \\
\hline CPI inflation & 0.7555 & 0.0016 & 0.0511 & 0.1916 \\
Output gap & 0.0500 & 0.8288 & 0.1120 & 0.0090 \\
Interest rate & 0.5050 & 0.0031 & 0.3692 & 0.1226 \\
Misalignment & 0.1772 & 0.0127 & 0.1606 & 0.6493 \\
\hline
\end{tabular}

$\mathrm{CPI}=$ consumer price index.

Source: Authors' calculations using data from CEIC Data Company, Federal Reserve Economic Data, and Haver Analytics (accessed 2 August 2020).

\section{ECONOMY-SPECIFIC BAYESIAN VECTOR AUTOREGRESSION}

As Asia and the Pacific is highly heterogeneous, the pooled VAR analysis may obscure the potential contributions that RER misalignment has on the business cycle. For example, the previous analyses show that shocks to RER misalignment have an impact on interest rate and CPI inflation but have weak or statistically insignificant effects on output gap. Interestingly, when we repeat our analysis for misalignment-volatile and misalignment-stable economies, we can see that most of the fluctuations in the pooled VAR analysis are driven by the subsample of misalignment-volatile economies.

This suggests that economies in Asia and the Pacific are highly heterogeneous in the context of the linkage between RER misalignment with CPI inflation, output gap, and interest rate. Thus, in this section, we estimate an economy-specific VAR for selected economies. We employ Bayesian VARs (BVARs) as opposed to standard VARs to avoid the curse of dimensionality present in the latter. ${ }^{21} \mathrm{We}$ will employ mostly three lags to estimate the BVAR for each economy. For most economies, we will estimate a 4-variable BVAR in the order of CPI inflation, output gap, interest rate, and misalignment as before. For economies where interest rate data are missing, we will estimate a three-variable BVAR instead.

${ }^{21}$ This is the case where the number of parameters grow by $p k^{2}$ ( $p$ is the number of lags and $k$ is the number of variables in the $\mathrm{VAR}$ ). 
Selected economies in Southeast Asia. Figure 12 plots the BVAR for five countries in Southeast Asia: Indonesia, Malaysia, the Philippines, Singapore, and Thailand. With the exception of Malaysia, there is evidence that an RER overvaluation shock leads to an increasingly negative output gap over the first 3 quarters (Singapore and Thailand) to 6 quarters (Indonesia). Unlike the baseline pooled VAR, the magnitude of the response by output gap is rather large. For example, for Indonesia, a one-standard deviation orthogonalized RER misalignment shock resulted in an RER overvaluation of about $6.8 \%$ on impact, before it converged toward zero. This was then followed by a decline in output gap, which bottomed out at about -0.12 log point after 6 quarters. This translates to about a 12\% decline in output relative to its trend following an initial RER overvaluation of $6.8 \%$, a strong response compared to what the baseline results have shown.

Besides Indonesia, the output gaps of the other economies also respond strongly to their respective RER misalignment shocks. For instance, Thailand's RER was overvalued by $1.6 \%$ on impact following a one-standard deviation orthogonalized RER misalignment shock. However, 3 quarters later, its output declined by more than $10 \%$ relative to the trend. Similarly, Singapore's RER was overvalued by $1.2 \%$ on impact, but its output gap later declined by about $6 \%$. Therefore, Southeast Asia appears to be susceptible to RER misalignment shocks.

Concerning the impact of RER misalignment on CPI inflation and interest rate, we find that for economies other than the Philippines, an RER overvaluation shock leads to a smaller decline in CPI inflation compared to the baseline. We also find that the impact of RER misalignment on interest rate is mostly statistically insignificant, except for Thailand, whose interest rate fell by 0.4 percentage points over the first 3 quarters before recovering toward zero. Interestingly, for Southeast Asia, the RER overvaluation shock on RER misalignment tends to be quite persistent. For Malaysia, it takes 16 quarters for RER misalignment to converge to zero following an RER overvaluation shock. For Thailand and Indonesia, however, RER misalignment appears to be less persistent. For the Philippines and Singapore, it takes RER misalignment about 10 quarters to go to zero following an RER overvaluation shock.

Hong Kong, China and the People's Republic of China. From Figure 13, there is little evidence that RER misalignment shocks matter for the output of Hong Kong, China and the PRC. A one-standard deviation orthogonalized RER misalignment shock leads to a small decline in CPI inflation of about 0.3 percentage points in Hong Kong, China and no significant effect in the PRC.

While the interest rate has a sizable response to RER misalignment shock, the response is statistically insignificant. For these economies, their RERs revert fairly quickly when misaligned. For instance, following a one-standard RER misalignment shock, their RERs become overvalued by about 0.02 log points (or $2 \%$ relative to the equilibrium). However, by 2 quarters, the PRC's RER misalignment index reverted back to zero. For Hong Kong, China, it took 10 quarters. This is still quite fast compared to most economies in Southeast Asia, where RER misalignment took 14 quarters or more to revert to zero. 


\section{Figure 12: Impulse Response from Orthogonalized Misalignment Shock- Selected Economies in Southeast Asia}

(a) Indonesia

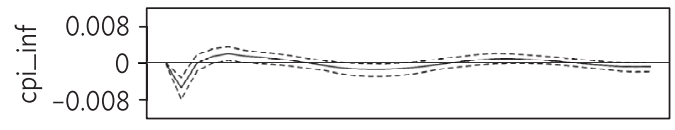

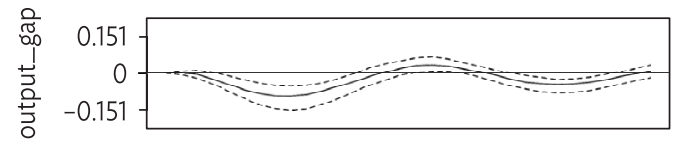
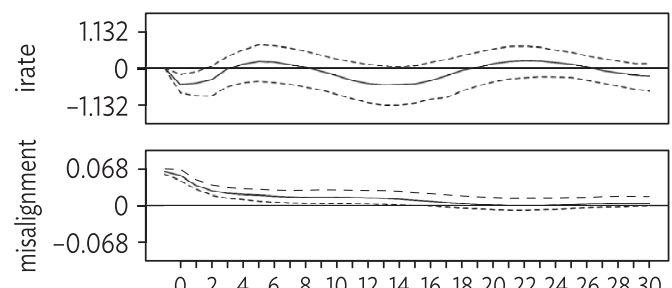

$\begin{array}{llllllllllllllll}0 & 2 & 4 & 6 & 8 & 10 & 12 & 14 & 16 & 18 & 20 & 22 & 24 & 26 & 28 & 30\end{array}$

(c) Philippines
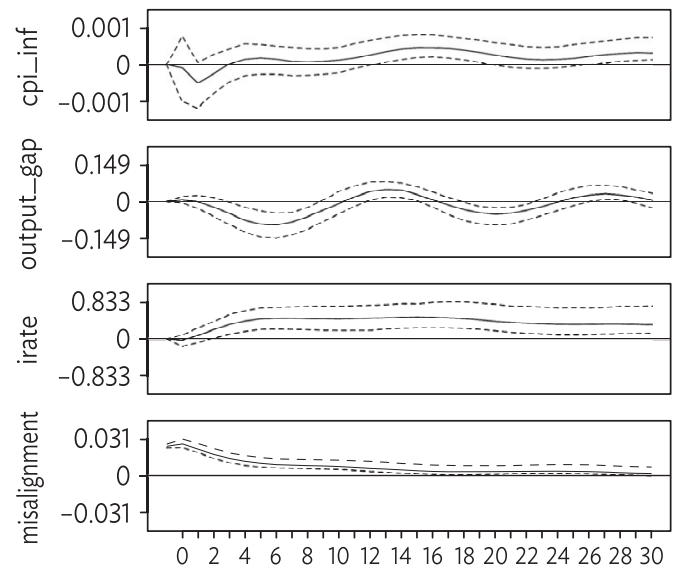

(e) Thailand
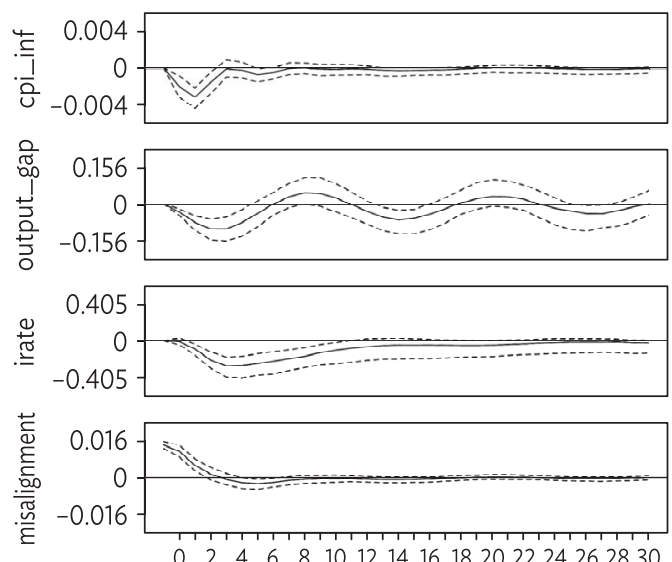

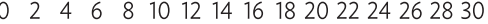

(b) Malaysia
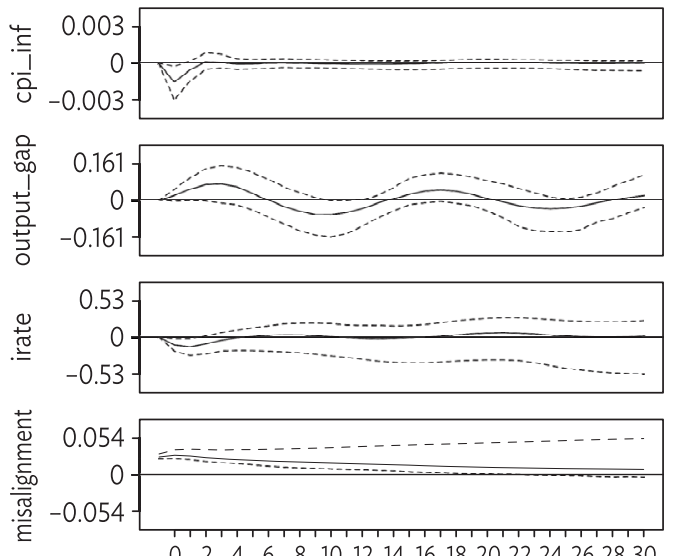

(d) Singapore
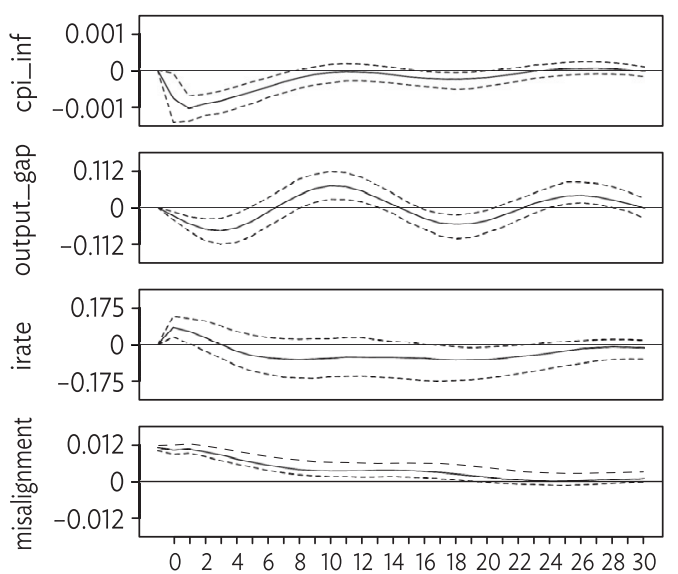

$\begin{array}{llllllllllllll}0 & 2 & 4 & 6 & 8 & 10 & 12 & 14 & 16 & 182022 & 24262830\end{array}$

$\mathrm{cpi} \_$inf $=$consumer price index inflation, irate $=$interest rate, misalignment $=$real exchange rate misalignment.

Note: A Bayesian vector autoregression with three lags is estimated for each country.

Source: Authors' calculations using data from CEIC Data Company, Federal Reserve Economic Data, and Haver Analytics (accessed 2 August 2020) 


\section{Figure 13: Impulse Response from Orthogonalized Misalignment Shock- Hong Kong, China and the People's Republic of China}

(a) People's Republic of China
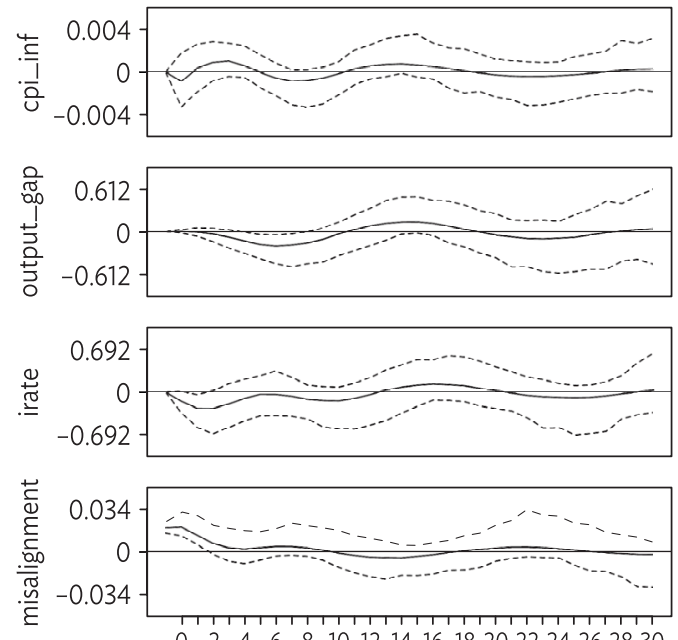

$0 \begin{array}{lllllllll}0 & 2 & 6 & 8 & 10 & 12 & 14 & 16 & 18202224262830\end{array}$ (b) Hong Kong, China
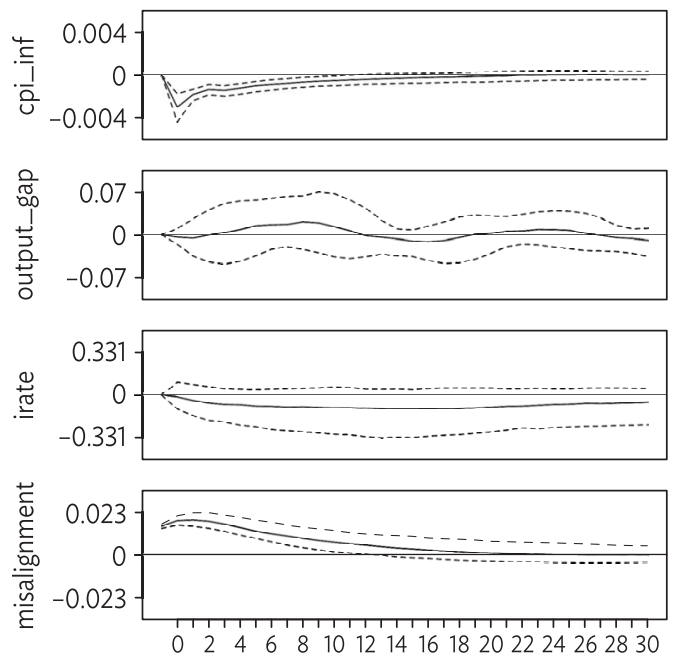

cpi_inf = consumer price index inflation, irate $=$ interest rate, misalignment $=$ real exchange rate misalignment.

Note: A Bayesian vector autoregression with three lags is estimated for each economy.

Source: Authors' calculations using data from CEIC Data Company, Federal Reserve Economic Data, and Haver Analytics (accessed 2 August 2020).

Selected economies in Central Asia. We consider Armenia, Azerbaijan, Kazakhstan, the Kyrgyz Republic, and Tajikistan. Because interest rate data are missing for Armenia, the Kyrgyz Republic, and Tajikistan, Figure 14 plots the impulse responses based on a three-variable BVAR for them.

For Azerbaijan and the Kyrgyz Republic, their output gaps respond quite significantly to RER misalignment shocks. For instance, following a one-standard deviation orthogonalized RER misalignment shock, where Azerbaijan's RER became overvalued by 5.5\% on impact, its output fell by close to $10 \%$ relative to the trend after 8 quarters. Similarly, the Kyrgyz Republic's RER was overvalued by about $3 \%$ on impact, but its output fell by close to $12 \%$ after 5 quarters.

An RER misalignment shock leads to a fall in CPI inflation of about 0.8 percentage points in Armenia and 0.5 percentage points in the Kyrgyz Republic. However, for the other economies in Central Asia, CPI inflation only responds weakly to RER overvaluation. For Azerbaijan and Kazakhstan, where we have data on interest rates, we find that interest rates do not respond much to RER misalignment shocks.

Among the economies in Central Asia, Kazakhstan and Tajikistan have the most persistent RER misalignment response following an RER overvaluation shock. As discussed in Section 3, this could be because Kazakhstan's RER has been misaligned for a lengthy period of time since mid-2000s, as shown in Figure 1. Similarly, Tajikistan's RER has been misaligned after the Global Financial Crisis and has not recovered since. 
Figure 14: Impulse Response from Orthogonalized Misalignment ShockSelected Economies in Central Asia

(a) Azerbaijan

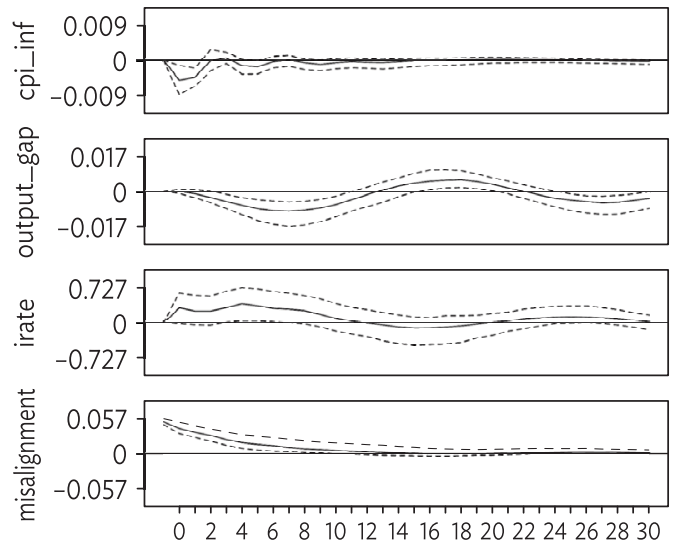

(c) Armenia
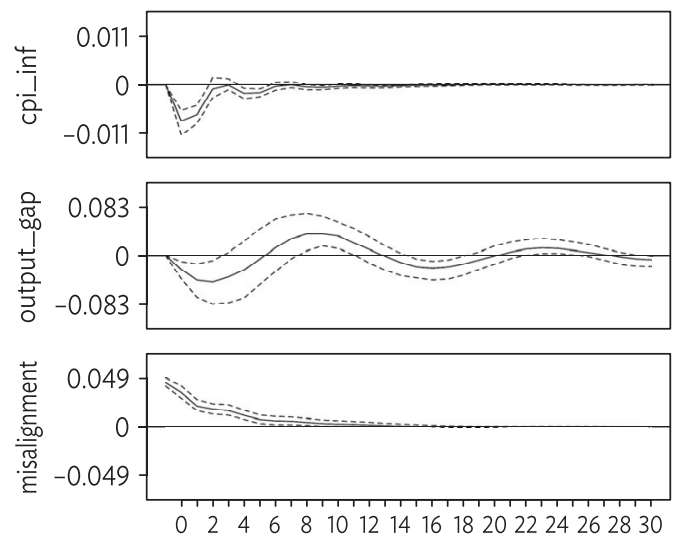

(e) Tajikistan

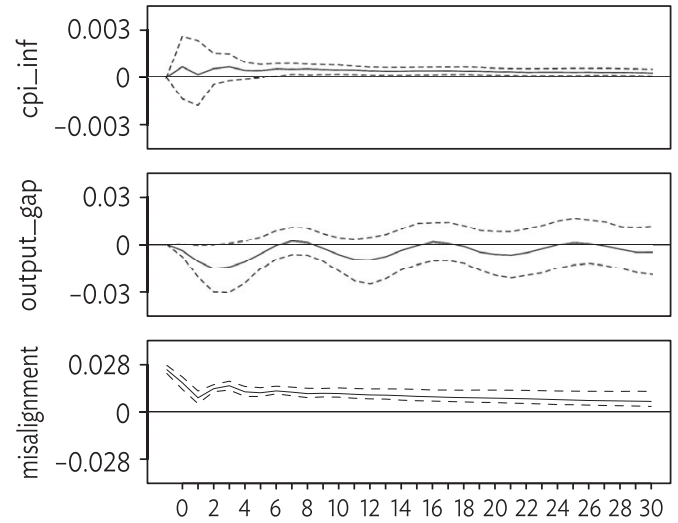

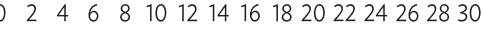

(b) Kazakhstan

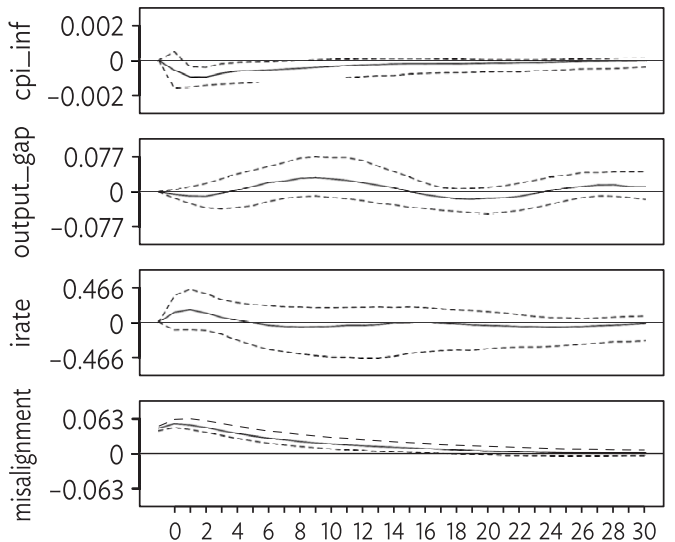

(d) Kyrgyz Republic
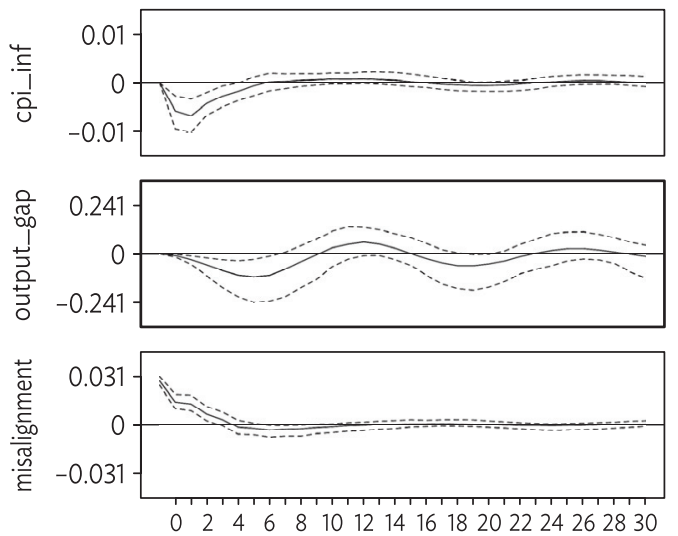

$\begin{array}{llllllllllllll}0 & 2 & 4 & 6 & 8 & 10 & 12 & 14 & 16 & 182022 & 24262830\end{array}$

cpi_inf = consumer price index inflation, irate = interest rate, misalignment = real exchange rate misalignment.

Note: A Bayesian vector autoregression with the lags is estimated for each country. For Armenia, the Kyrgyz Republic, and Tajikistan, a three-variable BVAR is estimated as interest rate data are not available.

Source: Authors' calculations using data from CEIC Data Company, Federal Reserve Economic Data, and Haver Analytics (accessed 2 August 2020). 
Fiji and the Solomon Islands. Figure 15 shows that an RER overvaluation shock reduces CPI inflation in the Solomon Islands. The misalignment of Fiji's and Solomon Islands' RER tend to be persistent after an overvaluation shock. However, there is little evidence that an RER misalignment shock has an impact on output gap.

\section{Figure 15: Impulse Response from Orthogonalized Misalignment Shock- Fiji and the Solomon Islands}

(a) Fiji
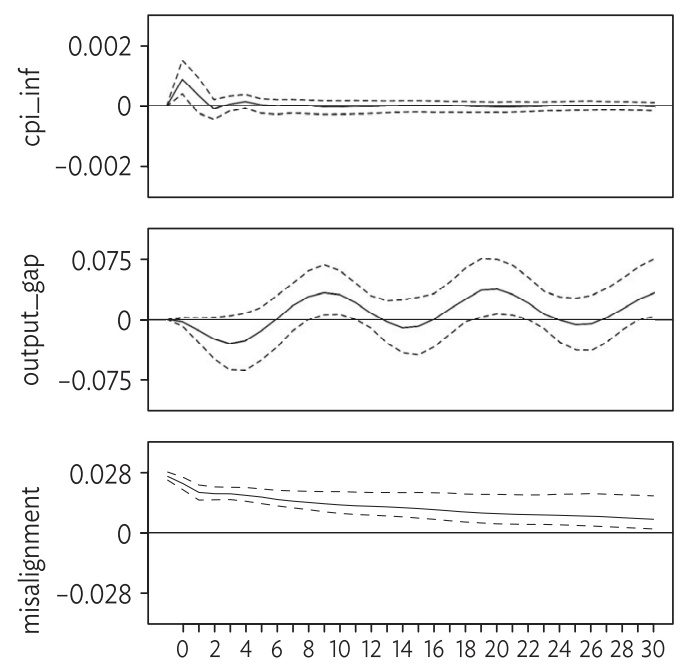

(b) Solomon Islands
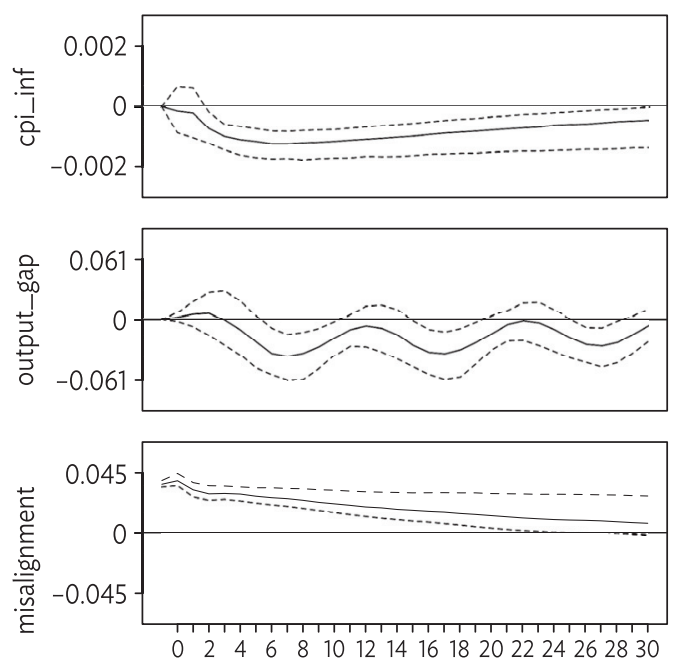

$\mathrm{cpi} \_$inf $=$consumer price index inflation, misalignment = real exchange rate misalignment.

Note: A Bayesian vector autoregression (BVAR) with three lags is estimated for each economy. A three-variable BVAR is estimated as interest rate data are not available.

Source: Authors' calculations using data from CEIC Data Company, Federal Reserve Economic Data, and Haver Analytics (accessed 2 August 2020). 


\section{CONCLUSIONS}

Over the years, the problem of RER misalignment has come under increasing scrutiny as many studies have shown that RER misalignment may slow down economic growth, restrict exports, and foment civil conflict and political instability. Much of the literature, however, focuses on the long-run implications of RER misalignment while little is known about its short-to-medium run impact on the economy.

This paper investigated the interaction between RER misalignment and macroeconomic performance in Asia and the Pacific. Using quarterly data from 1990 to 2018 on 22 economies in the region, we estimate a four-variable VAR that is ordered from CPI inflation, output gap, interest rate, and RER misalignment. We first estimate a pooled panel VAR model that accounts for unobserved heterogeneity. As the region is highly heterogenous, we also conduct a VAR analysis by economy using a Bayesian approach.

Our study documents the following observations about the interaction between RER misalignment and the other macroeconomic indicators:

- $\quad$ RER misalignment is affected by shocks to the CPI inflation and interest rate but not by shocks to the output gap. ${ }^{22}$

- We find that RER overvaluation may cause output to fall below its trend, where a $1 \%$ overvaluation in the RER is associated with a $1 \%$ decline in output relative to its trend. ${ }^{23}$

- RER misalignment is highly persistent. Once a currency is misaligned, it may take many years before the misalignment reverts to zero. Finally, for certain areas within the region, particularly in Southeast Asia, severe RER misalignment could be destabilizing. For instance, for Singapore and Thailand, we find that a small RER overvaluation may lead to a large negative output gap. This suggests that economies that are highly dependent on trade and tourism should focus on managing currency misalignments.

22 Following a one-standard deviation orthogonalized shock to CPI inflation, where the latter increased by 1.5 percentage points on impact, the RER eventually became overvalued by more than $1 \%$ several quarters after. Likewise, the RER eventually became overvalued by the same amount following a shock to interest rate that drives it up by 1.4 percentage points increase impact.

23 This comes from the fact that following a one-standard deviation orthogonalized shock to RER misalignment, the RER became overvalued by close to 0.05 log points (i.e. $5 \%$ ). Several quarters later, output gap fell by slightly more than 0.05 log points (i.e. $5 \%$ ). 


\section{REFERENCES}

Ambaw, Dessie Tarko, and Nicholas Sim. 2021. "Real Exchange Rate Misalignment and Civil Conflict: Evidence from Sub-Saharan Africa." Oxford Economic Papers 73 (1): 178-99.

Anderson, Theodore W., and Cheng Hsiao. 1982. "Formulation and Estimation of Dynamic Models Using Panel Data." Journal of Econometrics 18 (1): 47-82.

Béreau, Sophie, Antonia López Villavicencio, and Valérie Mignon. 2012. "Currency Misalignments and Growth: A New Look Using Nonlinear Panel Data Methods.” Applied Economics 44 (27): 3503-11.

Comunale, Mariarosaria. 2021. "A Panel VAR Analysis of Macro-Financial Imbalances in the EU." Journal of International Money and Finance: 102511.

Cottani, Joaquin A., Domingo F. Cavallo, and M. Shahbaz Khan. 1990. "Real Exchange Rate Behavior and Economic Performance in LDCs." Economic Development and Cultural Change 39 (1): 61-76.

Cubeddu, Luis M., Signe Krogstrup, Gustavo Adler, Pau Rabanal, Mai Chi Dao, Swarnali Hannan, Luciana Juvenal, Carolina Osorio Buitron, Cyril Rebillard, Daniel Garcia-Macia, Callum Jones, Jair Rodriguez, Kyun Suk Chang, Deepali Gautam, Zijiao Wang, and Nan Li. 2019. "The External Balance Assessment Methodology: 2018 Update." IMF Working Paper No. 19/6. International Monetary Fund, Washington, DC.

Edwards, Sebastian. 1989. "Exchange Rate Misalignment in Developing Countries.” The World Bank Research Observer 4 (1): 3-21.

Elbadawi, Ibrahim A. 1998. Real Exchange Rate Policy and Non-Traditional Exports in Developing Countries. Helsinki, Finland: UNU-WIDER.

Elbadawi, Ibrahim A., Linda Kaltani, and Raimundo Soto. 2012. "Aid, Real Exchange Rate Misalignment, and Economic Growth in Sub-Saharan Africa.” World Development 40 (4): 681-700.

Engel, Charles. 2014. "Exchange Rate Stabilization and Welfare.” Annual Review of Economics 6 (1): 155-77.

—. 2011. "Currency Misalignments and Optimal Monetary Policy: A Reexamination.” The American Economic Review 101 (6): 2796-822.

Freund, Caroline, and Martha Denisse Pierola. 2012. "Export Surges." Journal of Development Economics 97 (2): 387-95.

Ghura, Dhaneshwar, and Thomas J. Grennes. 1993. "The Real Exchange Rate and Macroeconomic Performance in Sub-Saharan Africa.” Journal of Development Economics 42 (1): 155-74.

Gnimassoun, Blaise, and Valérie Mignon. 2016. "How Do Macroeconomic Imbalances Interact? Evidence from a Panel VAR Analysis." Macroeconomic Dynamics 20 (7): 1717-41. 
Gnimassoun, Blaise, and Valérie Mignon. 2015. "Persistence of Current-Account Disequilibria and Real Exchange-Rate Misalignments." Review of International Economics 23 (1): 137-59.

Goldfajn, Ilan, and Rodrigo O. Valdes. 1999. "The Aftermath of Appreciations." The Quarterly Journal of Economics 114 (1): 229-62.

Habib, Maurizio Michael, Elitza Mileva, and Livio Stracca. 2017. "The Real Exchange Rate and Economic Growth: Revisiting the Case Using External Instruments." Journal of International Money and Finance 73: 386-98.

Heriqbaldi, Unggul, Wahyu Widodo, and Dian Ekowati. 2020. "Real Exchange Rate Misalignment and Currency Crises." Bulletin of Indonesian Economic Studies 56 (3): 345-62.

Holtemöller, Oliver, and Sushanta Mallick. 2013. "Exchange Rate Regime, Real Misalignment and Currency Crises." Economic Modelling 34: 5-14.

Holtz-Eakin, Douglas, Whitney Newey, and Harvey S. Rosen. 1988. "Estimating Vector Autoregressions with Panel Data." Econometrica 56 (6): 1371-95.

Houssa, Romain, Jolan Mohimont, and Christopher Otrok. 2015. "Sources of Business Cycles in a Low Income Country.” Pacific Economic Review 20 (1): 125-48.

Lewis, Mark, Aurelie Martin, and Gabriel Di Bella. 2007. "Assessing Competitiveness and Real Exchange Rate Misalignment in Low-Income Countries." IMF Working Paper No. 07/201. International Monetary Fund, Washington, DC.

MacDonald, Ronald. 2000. "Concepts to Calculate Equilibrium Exchange Rates: An Overview." Discussion Paper Series 1, No. 2000,03. Deutsche Bundesbank, Frankfurt.

Montiel, Peter J. 1999. "The Long-Run Equilibrium Real Exchange Rate: Conceptual Issues and Empirical Research." In Exchange Rate Misalignment: Concepts and Measurement for Developing Countries, edited by Lawrence E. Hinkle and Peter J. Montiel, 219-63. Washington, DC: World Bank.

Nurkse, Ragnar. 1945. "Conditions of International Monetary Equilibrium.” Essays in International Finance No. 4. Department of Economics and Social Institutions, Princeton University, Princeton, NJ.

Pesaran, M. Hashem. 2007. "A Simple Panel Unit Root Test in the Presence of Cross-Section Dependence." Journal of Applied Econometrics 22 (2): 265-312.

Pesaran, M. Hashem, Yongcheol Shin, and Ron P. Smith. 1999. "Pooled Mean Group Estimation of Dynamic Heterogeneous Panels.” Journal of the American Statistical Association 94 (446): 621-34.

Pick, Daniel H., and Thomas L. Vollrath. 1994. "Real Exchange Rate Misalignment and Agricultural Export Performance in Developing Countries." Economic Development and Cultural Change 42 (3): 555-71.

Rodrik, Dani. 2008. "The Real Exchange Rate and Economic Growth.” Brookings Papers on Economic Activity 39 (2): 365-439. 
Sekkat, Khalid. 2016. "Exchange Rate Misalignment and Export Diversification in Developing Countries." The Quarterly Review of Economics and Finance 59: 1-14.

Sekkat, Khalid, and Aristomene Varoudakis. 2000. "Exchange Rate Management and Manufactured Exports in Sub-Saharan Africa." Journal of Development Economics 61 (1): 237-53.

Staehr, Karsten, and Robert Vermeulen. 2016. "How Competitiveness Shocks Affect Macroeconomic Performance across Euro Area Countries.” ECB Working Paper No. 1940. European Central Bank, Frankfurt a. M. 


\section{Real Exchange Rate Misalignment and Business Cycle Fluctuations in Asia and the Pacific}

This paper investigates the impact of real exchange rate (RER) misalignment on business cycles among 22 economies in Asia and the Pacific from 1990 to 2018. It employs a panel vector autoregression involving consumer price index (CPI) inflation, output gap, short-term interest rate, and RER misalignment.

The authors find that RER overvaluation may lead to a reduction in CPI inflation and short-term interest rate. The study also illustrates Asia and the Pacific's heterogeneity as evidenced by the output gaps of some economies, particularly in Southeast Asia, which are shown to be more susceptible to RER misalignment shocks.

\section{About the Asian Development Bank}

ADB is committed to achieving a prosperous, inclusive, resilient, and sustainable Asia and the Pacific, while sustaining its efforts to eradicate extreme poverty. Established in 1966, it is owned by 68 members -49 from the region. Its main instruments for helping its developing member countries are policy dialogue, loans, equity investments, guarantees, grants, and technical assistance. 